$11-1-2006$

\title{
Living with the Bologna Process: Recommendations to the German Legal education Community from a U.S. Perspective
}

Laurel S. Terry

Iterry@psu.edu

Follow this and additional works at: https://ideas.dickinsonlaw.psu.edu/fac-works

Part of the Comparative and Foreign Law Commons, Legal Ethics and Professional Responsibility Commons, and the Legal Profession Commons

\section{Recommended Citation}

Laurel S. Terry, Living with the Bologna Process: Recommendations to the German Legal education Community from a U.S. Perspective, 7 German L.J. 863 (2006).

This Article is brought to you for free and open access by the Faculty Scholarship at Dickinson Law IDEAS. It has been accepted for inclusion in Faculty Scholarly Works by an authorized administrator of Dickinson Law IDEAS. For more information, please contact lja10@psu.edu. 


\title{
Living with the Bologna Process: Recommendations to the German Legal Education Community from a U.S. Perspective
}

\author{
By Laurel S. Terry
}

\section{A. Introduction: Placing the Bologna Process in Context}

The Bologna Process is a dramatic development that is less than ten years old, but already it has significantly reshaped higher education in Germany and in Europe. This article is based on my research regarding the history and objectives of the Bologna Process ${ }^{1}$ and Bologna Process implementation in Germany. ${ }^{2}$ It contains my reflections about the Bologna Process and German legal education and my recommendations to the German legal education community. In order to understand these reflections and recommendations, one needs a certain amount of background information about both the Bologna Process and German legal education. The sections that follow provide that background.

\section{B. The Bologna Process}

The Bologna Process began in 1998 with a written understanding signed by the ministers of four European Union (EU) countries. ${ }^{3}$ By 2005, the Bologna Process

\footnotetext{
* Professor Laurel S. Terry. Penn State Dickinson School of Law. Email: LTerry@psu.edu. Although many individuals provided assistance, the author would like to especially thank Professor Dr. Martin Henssler, Dr. Matthias Kilian, Dr. Wolfgang Eichele, Dr. Julian Lonbay, Professor Helen Hartnell and the German-American Fulbright Association for their assistance and support.

${ }^{1}$ Laurel S. Terry, The Bologna Process and the Dramatically Changing Nature of Legal Education in Europe, (2006), available soon at www.ssrn.com [hereinafter Terry, The Bologna Process and Legal Education]. See also Laurel S. Terry, The Bologna Process and Its Implications for U.S. Legal Education, 57 JOURNAL OF LEGAL EDUCATION (forthcoming 2007) (reflections and recommendations to the U.S. legal community about the Bologna Process)

2 Laurel S. Terry, German Legal Education and the Challenges of Implementing the Bologna Process: A Case Study (2006), available soon at www.ssm.com [hereinafter Terry, The Bologna Process: A German Case Study].

3 Joint Declaration on Harmonisation of the Architecture of the European Higher Education System By the Four Ministers in Charge for France, Germany, Italy and The United Kingdom, May 25, 1998,
} 
had expanded to forty-five participating countries, including all of the EU countries and twenty non-EU countries. ${ }^{4}$ The Bologna Process is not an official EU project, but there is a great deal of overlap between the Bologna Process and various EU initiatives, including the EU's Lisbon Strategy, which is designed to make the EU "the most competitive and dynamic knowledge-based economy in the world." The Bologna Process participants have called for close cooperation with the EU. ${ }^{6}$

The Bologna Process countries have announced their intention to form the European Higher Education Area (EHEA) by 2010.7 The goals of the EHEA and the Bologna Process evolved through a series of five meetings and the work leading up to those meetings. During these meetings, the participants significantly expanded

available at http:/ / www.bologna-bergen2005.no/Docs/00-Main_doc/980525SORBONNE_ DECLARATION.PDF [hereinafter Sorbonne Declaration].

4 The European Higher Education Area - Achieving the Goals, Communique of the Conference of European Ministers Responsible for Higher Education, p. 6 May 19-20, 2005, available at http://www.bologna-bergen2005.no/Docs/00-Main_doc/050520_Bergen_Communique.pdf,

[hereinafter Bergen Communiqué]. See also From Berlin to Bergen: General Report of the Bologna Follow-up Group to the Conference of European Ministers Responsible for Higher Education, p. 40-41 May 3, 2005, available at http://www.bologna-bergen2005.no/Bergen/050503_General_rep.pdf, [hereinafter Bologna Follow-up Group Report for the Bergen Ministerial Meeting] (explaining the procedures for admission into the Bologna Process and the acceptance of the applications from Armenia, Azerbaijan, Georgia, Moldova and Ukraine, but not Kazakhstan or Kosovo, both of which may be accepted in 2007 during the London Ministerial meeting).

${ }^{\circ}$ Lisbon European Council: Presidency Conclusions (EC), Nr: 100/1/00 at 1, Mar. 24, 2000, available at http://ue.eu.int/ueDocs/cms_Data/docs/pressData/en/ec/00100-r1.en0.htm [hereinafter Lisbon Strategy] (setting forth the Lisbon Strategy; this was later reaffirmed and expanded in Barcelona in 2002). See also European Council, Detailed Work Programme On The Follow-Up Of The Objectives Of Education And Training Systems In Europe, 2002 O.J. (C 142) 1.

"Bergen Communiqué, supra note 4, at 2 ("Ministers take into due consideration the conclusions [of the Lisbon Strategy and call] for further action and closer co-operation in the context of the Bologna Process."). See supra note 5 for more information on the Lisbon Strategy.

${ }_{7}$ Joint Declaration of the European Ministers of Education, The Bologna Declaration of 19 June 1999, p. 3, available at http://www.bologna-bergen2005.no/Docs/00Main_doc/990719BOLOGNA_DECLARATION.PDF, [hereinafter Bologna Declaration] ("While affirming our support to the general principles laid down in the Sorbonne declaration, we engage in coordinating our policies to reach in the short term, and in any case within the first decade of the third millennium, the following objectives, which we consider to be of primary relevance in order to establish the European area of higher education and to promote the European system of higher education worldwide..."). See also Towards the European Higher Education Area: Communique of the meeting of European Ministers in charge of Higher Education in Prague on May 19th 2001, p. 1, available at http://www.bologna-bergen2005.no/Docs/00-Main_doc/ 010519PRAGUE_COMMUNIQUE.PDF, [hereinafter Prague Communiqué] ("We confirm our commitment to coordinating our policies through the Bologna Process to establish the European Higher Education Area (EHEA) by 2010..."). The year 2010 is not mentioned in the Sorbonne Declaration. See Sorbonne Declaration, supra note 3. 
the Bologna Process objectives and work program. ${ }^{8}$ The results of the first two meetings are contained in the 1998 Sorbonne Declaration and the 1999 Bologna Declaration. ${ }^{9}$ The results of the next three meetings are memorialized in documents called "communiqués." 10 To date, the Bologna Process ministers have adopted the 2001 Prague Communiqué, 11 the 2003 Berlin Communiqué $e^{12}$ and the 2005 Bergen Communiqué.13 During their 2005 Bergen meeting, the Ministers also adopted two additional documents - the European Quality Assurance Standards ${ }^{14}$ and the Framework of Qualifications for the European Higher Education Area. ${ }^{15}$ The Standards provide guidelines for internal and external quality assurance standards as well as guidelines for external quality assurance agencies. The Framework of Qualifications provides suggested credits necessary for the different types of degrees and the recommended outcomes a student should achieve at each degree level.

The Bologna Process has an official "Secretariat" that rotates every two years and is hosted by the country where the upcoming ministerial meeting will be held. ${ }^{16}$ Because the Bologna Process ministers will next meet in 2007 in London, the current Bologna Process Secretariat is based in the United Kingdom. ${ }^{17}$ Beginning with the 2003 Berlin meeting, there has been an extensive Bologna Process website on which

\footnotetext{
8 See supra notes $3-5,7$ and infra note 12 .

9 See Sorbonne Declaration, supra note 3. See also Bologna Declaration, supra note 7.

10 See supra notes 4, 7 and infra note 12 .

11 Prague Communiqué, supra note 7.

12 Realising the European Higher Education Area: Communiqué of the Conference of Ministers responsible for Higher Education in Berlin on 19 September 2003, p. 1, available at http://www.bolognabergen2005.no/Docs/00-Main_doc/ 030919Berlin_Communique.PDF [hereinafter Berlin Communiqué].

13 See Bergen Communiqué, supra note 4.
}

14 European Quality Assurance Standards, available at http://www.bologna-bergen 2005.no/EN/BASIC/Quality_Assurance_Standards.HTM.

15 Framework of Qualifications for the European Higher Education Area, available at http://www.bologna-bergen2005.no/EN/BASIC/Framework_Qualifications.HTM (addresses outcomes for the three cycles of degrees and target credits).

16 Berlin Communiqué, supra note 12, at 8 ("The overall follow-up work will be supported by a Secretariat which the country hosting the next Ministerial Conference will provide.").

17 UK Bologna Secretariat Website, http://www.dfes.gov.uk/bologna/ [hereinafter UK Bologna Secretariat Website] (last visited July 5, 2006) ("From 1 July 2005 the UK has taken over responsibility for the Secretariat to the Bologna Follow Up Group and its Board. Our aim is to provide information and news about developments in the Bologna Process and about how the work programme will be taken forward over the next two years prior to the next Ministerial Summit in London in May 2007."). 
materials are posted in advance of the ministerial meeting. ${ }^{18}$ Websites that were created for the 2003 Berlin meeting and the 2005 Bergen meeting have been frozen in time and are still available; they contain historical information, documents and studies. ${ }^{19}$ The current Bologna Process UK Secretariat website includes links to new documents as well as links to the prior website. ${ }^{20}$

Both the official Bologna Process website and official Bologna Process documents refer to the following ten goals, or "action lines", that have emerged over the past eight years:

\section{Introduced in the 1999 Bologna Declaration:}

Adoption of a system of easily readable and comparable degrees;

Adoption of a system essentially based on two cycles;

Establishment of a system of credits;

Promotion of mobility;

Promotion of European co-operation in quality assurance;

Promotion of the European dimension in higher education;

\section{Introduced in the 2001 Prague Communiqué:}

\section{Lifelong learning;}

The partnership of higher education institutions and students;

Promoting the attractiveness of the European Higher Education Area (EHEA); and

\section{Introduced in the 2003 Berlin Communiqué:}

Expansion of the focus on two degree cycles to include a third degree cycle of doctoral studies

\footnotetext{
18 See Bundesministerium für Bildung und Forschung, Bologna Process: Towards the European Higher Education Area, Berlin 2003, available at http://www.bologna-berlin2003.de/ [hereinafter Berlin Bologna Website].

${ }^{19}$ See Berlin Bologna Website, supra note 18. See also Bergen Secretariat, Bologna Process Official Webpage, http://www.bologna-bergen2005.no/EN/About/Web1.HTM [hereinafter Bergen Bologna Website] (last visited July 5, 2006) (follow "About the Website").

${ }^{20}$ UK Bologna Secretariat Website, supra note 17 (links listed on homepage).
} 
and synergy between the EHEA and the European Research Area (ERA). ${ }^{21}$

In addition to listing these ten action lines, the official Bologna Process website and documents state that the social dimension of higher education might be seen as an overarching action line. ${ }^{22}$

In anticipation of the 2005 Bergen ministerial meeting, the Bologna participants identified three goals as their immediate priority objectives: 1) achieving a twodegree (bachelor-master) cycle; 2) quality assurance programs; and 3) recognition of degrees. ${ }^{23}$ In order to measure their progress on these three priority objectives, the Bologna Ministers decided that a Stocktaking Report should be prepared for the 2005 Bergen meeting. ${ }^{24}$ The 2005 Stocktaking Report identified ten benchmarks that were used to measure progress on the three priority objectives. For example, to gauge progress on the first objective of quality assurance, the 2005 Stocktaking Report measured the stage of development of quality assurance systems; the key elements of evaluation systems; the level of participation of students; and the level of international participation, co-operation, and networking. ${ }^{25}$ To measure progress on the second priority objective, involving the two-degree cycle, the 2005 Stocktaking Report used three benchmarks that measured each country's stage of implementation of a two-cycle system; the level of student enrolment in a twocycle system; and access from the first cycle to the second cycle. ${ }^{26}$ To measure progress on the third priority objective, which involved the recognition of degrees from one country by another, the 2005 Stocktaking Report also used three benchmarks. ${ }^{27}$ These benchmarks were: the stage of implementation of the

\footnotetext{
21 Bergen Bologna Website, supra note 19; Work Programme Action Lines, http://www.bolognabergen2005.no/EN/Work_prog/1Prog_Back-Action_lines.HTM [hereinafter Bologna Action Lines] (follow "Basic Information") (these ten "action lines" were taken from the official Bologna Process Work Programme.).

22 See Bologna Action Lines, supra note 21.

23 See Berlin Communiqué, supra note 12 , at 7 .

24 See id. ("Ministers charge the Follow-up Group with organizing a stocktaking process in time for their summit in 2005 and undertaking to prepare detailed reports on the progress and implementation of the intermediate priorities set for the next two years....").

25 Bologna Process Stocktaking Report, p. 16, available at http://www.bologna-bergen2005.no/Bergen/ 050509_Stocktaking.pdf [hereinafter 2005 Stocktaking Report] (from a working group appointed by the Bologna Follow-up Group to the Conference of European Ministers Responsible for Higher Education, May 19-20, 2005).

$26 I d$. at 18 .

27 Id. at 21 .
} 
Diploma Supplement; ${ }^{28}$ whether the country had ratified the Lisbon Recognition Convention; ${ }^{29}$ and the stage of implementation of the European Credit Transfer and Accumulation System (ECTS). ${ }^{30}$ The 2005 Stocktaking Report used a color-coded

28 The Diploma Supplement referred to here is a standardized form that higher education institutions attach to each higher education diploma in order to explain its meaning to those from other countries. It is derived from an international convention or agreement that was reached under the auspices of the Council of Europe, the European Commission and the United Nations Educational, Scientific and Cultural Organization (UNESCO). The Diploma Supplement includes items such as the name of the degree; information on the contents of the degree, including the units studied, individual grades, the grading scheme and grade distribution; and information on whether the degree provides access to further study or confers professional status. UNESCO, Diploma Supplement, available at http://portal.unesco.org/

education/en/file_download.php/1bf758ecb6612b53c359b30e62749419Diploma+Supplement.pdf.

29 The Lisbon Convention referred to here is Council of Europe/UNESCO, Convention on the Recognition of Qualifications concerning Higher Education in the European Region, Apr. 11, 1997, ETS No. 165, available at http:/ conventions.coe.int/Treaty/en/Treaties/Html/165.htm [hereinafter Lisbon Convention]. See also Explanatory Report on the Convention on the Recognition of Qualifications concerning Higher Education in the European Region Apr. 11, 1997, ETS No. 165, available at http://conventions.coe.int/Treaty/EN/Reports/Html/165.htm [hereinafter Lisbon Convention Explanatory Memo]

According to a summary prepared for the Bologna Process, the nine main points in the Lisbon Convention are as follows: 1) holders of qualifications issued in one country shall have adequate access to an assessment of these qualifications in another country; 2) there should be no discrimination on any ground such as the applicant's gender; race; colour; disability; language; religion; political opinion; or national, ethnic or social origin; 3) the body undertaking the assessment has the responsibility to demonstrate that an application does not fulfil the relevant requirements; 4) each country has an obligation to recognize higher education qualifications and degrees as similar to its own unless it can show that there are substantial differences between its own qualifications and the qualifications for which recognition is sought; 5 ) recognition of a higher education qualification issued in another country shall have one or both of the following consequences: access to further higher education studies, including relevant examinations and preparations for the doctorate, on the same conditions as candidates from the country in which recognition is sought; and the use of an academic title, subject to the laws and regulations of the country in which recognition is sought; 6) all countries shall develop procedures to assess whether refugees and displaced persons fulfil the relevant requirements for access to higher education or to employment activities, even in cases in which the qualifications cannot be proven through documentary evidence; 7) all countries shall provide information on the institutions and programmes they consider as belonging to their higher education systems; 8) all countries shall appoint a national information centre, one important task of which is to offer advice on the recognition of foreign qualifications to students, graduates, employers, higher education institutions and other interested parties or persons and 9) all countries shall encourage their higher education institutions to issue the Diploma Supplement to their students in order to facilitate recognition. The Lisbon Convention - What is it?, http://www.bologna-bergen2005.no/Docs/03-PNY/Lisbon_for_pedestrians.pdf.

30 See European Commission, ECTS - European Credit Transfer and Accumulation System, http:/ / ec.europa.eu./education/programmes/socrates/ects/index_en.html (last visited June 27, 2006) ("ECTS began in 1989 as a system for transferring credits among ERASMUS and SOCRATES in order to facilitate study abroad."). The ECTS system is based on the principle that 60 credits measure the workload of a full-time student during one academic year. $I d$. As the European Commission explains, "Recently ECTS is developing into an accumulation system to be implemented at institutional, regional, 
ranking system to show the progress that each country had made on each one of these ten benchmarked items. ${ }^{31}$ For each country, the Report also provided a combined score for each of the three priority objectives and an overall score. ${ }^{32}$

The Stocktaking Report also included information about the progress that had been made by all Bologna Process participants, judged collectively. ${ }^{33}$ The Bologna Process countries gave themselves a collective score of light green, which means they rated themselves as having made "very good progress" overall. ${ }^{34}$ The participants also rated themselves as having made "very good progress" on each of the three priority objectives and on all but one of the ten benchmark items. ${ }^{35}$

Germany received one of the best scores in the 2005 Stocktaking Report. It was rated as having made "very good progress" overall and "very good progress" on each of the three priority objectives. ${ }^{36}$ The table below shows Germany's rating on each of the ten benchmark items and sets forth what was required in order to earn that rating. This table also includes Germany's cumulative score for each priority item, and its overall cumulative score.

national and European level. This is one of the key objectives of the Bologna Declaration of June 1999." ld.

312005 Stocktaking Report, supra note 25, at 40-106.

${ }^{32}$ Id.

$33 \mathrm{Id}$.

34 Id at 41.

${ }_{35} I d$.

$36 \mathrm{Id}$. at $40,78-79$. 
Table 1: Terry Summary of Germany's Rating in the 2005 Stocktaking Report

\begin{tabular}{|c|c|c|}
\hline & $\begin{array}{l}\text { Progress } \\
\text { Rating }\end{array}$ & 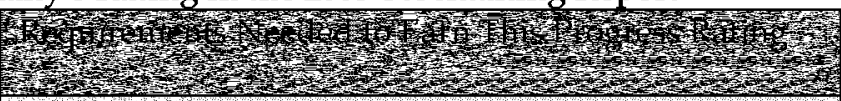 \\
\hline $\begin{array}{l}\text { CUMULATIVE } \\
\text { RATING }\end{array}$ & ondrats & \\
\hline \multicolumn{3}{|l|}{ Benchmark Rated: } \\
\hline $\begin{array}{l}\text { 1. Stage of development } \\
\text { of quality assurance } \\
\text { system }\end{array}$ & & $\begin{array}{l}\text { A Quality Assurance (QA) system is in operation at } \\
\text { the national level and applies to all Higher } \\
\text { Education,* with responsibilities of bodies and } \\
\text { institutions clearly defined } \\
\text { Fully functioning dedicated QA agency in place, } \\
\text { OR } \\
\text { Existing agencies have QA as part of responsibility } \\
\left({ }^{*} \text { As defined in the Lisbon Recognition Convention) }\right.\end{array}$ \\
\hline $\begin{array}{l}\text { 2. Key elements of } \\
\text { evaluation systems }\end{array}$ & Exed 104 & $\begin{array}{l}\text { The following five elements of evaluation systems } \\
\text { listed in the Berlin Communiqué are fully } \\
\text { implemented in all Higher Education: } \\
\text { internal assessment } \\
\text { - external review } \\
\text { participation of students } \\
\text { - publication of results } \\
\text { - international participation }\end{array}$ \\
\hline $\begin{array}{l}\text { 3. Level of participation } \\
\text { of students }\end{array}$ & & $\begin{array}{l}\text { Students participate at four levels of the evaluation } \\
\text { process: } \\
\text { - In the governance of national bodies for QA } \\
\text { Within teams for external review } \\
\text { - Consultation or involvement during external } \\
\text { reviews } \\
\text { Involvement in internal evaluations }\end{array}$ \\
\hline $\begin{array}{l}\text { 4. Level of international } \\
\text { participation, } \\
\text { cooperation and } \\
\text { networking }\end{array}$ & tragents & $\begin{array}{l}\text { International participation at three levels: } \\
\text { - In the governance of national bodies for QA } \\
\text { - In teams for external review } \\
\text { - Membership in ENQA or other international } \\
\text { networks }\end{array}$ \\
\hline $\begin{array}{l}\text { Average for Quality } \\
\text { Assurance } \\
\text { (Criteria 1-4) }\end{array}$ & & \\
\hline $\begin{array}{l}5 . \quad \text { Stage } \\
\text { implementation } \\
\text { two-cycle system } \\
\end{array}$ & 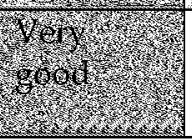 & $\begin{array}{l}\text { A two-cycle degree system is being implemented on } \\
\text { a limited scale in } 2005\end{array}$ \\
\hline
\end{tabular}




\begin{tabular}{|c|c|c|}
\hline & & W \\
\hline $\begin{array}{l}\text { 6. Level of student } \\
\text { enrollment in two-cycle } \\
\text { system }\end{array}$ & & $\begin{array}{l}25-50 \text { percent of students are enrolled in the two- } \\
\text { cycle system in } 2005\end{array}$ \\
\hline $\begin{array}{l}\text { from first } \\
\text { second cycle }\end{array}$ & & $\begin{array}{l}\text { There is access* for all students to at least one second } \\
\text { cycle programme without major transitional } \\
\text { problems } \\
\left({ }^{*} \text { Access means having the right to apply for }\right. \\
\text { admission) }\end{array}$ \\
\hline $\begin{array}{l}\text { Average for Two } \\
\text { Degree } \\
\text { (Criteria 5-7) }\end{array}$ & & \\
\hline $\begin{array}{l}8 . \quad \text { Stage of } \\
\text { implementation of } \\
\text { Diploma Supplement }\end{array}$ & & $\begin{array}{l}\text { Every student graduating in } 2005 \text { will receive the } \\
\text { Diploma Supplement automatically and free of } \\
\text { charge, issued in a widely-spoken European } \\
\text { language }\end{array}$ \\
\hline $\begin{array}{l}\text { 9. Ratification of Lisbon } \\
\text { Recognition } \\
\text { Convention }\end{array}$ & & $\begin{array}{l}\text { Convention has been signed and the process of } \\
\text { ratification has begun }\end{array}$ \\
\hline $\begin{array}{ll}10 . \quad \text { Stage } & \text { of } \\
\text { implementation } & \text { of } \\
\text { ECTS } & \\
\end{array}$ & & $\begin{array}{l}\text { ECTS credits are allocated in the majority of Higher } \\
\text { Education programmes, enabling credit transfer }\end{array}$ \\
\hline $\begin{array}{l}\text { Average } \\
\text { Recognition } \\
\text { Criteria } 8-10\end{array}$ & & \\
\hline
\end{tabular}

Shortly after the 2005 Stocktaking Report was published, the German government issued a press release citing its favorable ranking. ${ }^{37}$

The Bologna Process participants have agreed to conduct another Stocktaking Exercise in time for their 2007 London meeting and have identified an additional four items to measure as part of this 2007 stocktaking. ${ }^{38}$ These four items, which are related to the original three priority objectives, are:

\footnotetext{
37 Bundesministerium für Bildung und Forschung, Pressemitteilung 113/2005, Bulmahn: Die Konferenz von Bergen wird die Schaffung eines europäischen Hochschulraums voranbringen, available at http://www.bmbf.de/press/1468.php (noting Germany's favorable report regarding the degree cycle and quality assurance objectives).

38 Bergen Communiqué, supra note 4 , at 5 ("We charge the Follow-up Group with continuing and widening the stocktaking process and reporting in time for the next Ministerial Conference.").
} 
1) implementation of the standards and guidelines for quality assurance as proposed in the ENQA report; 39

2) implementation of the national frameworks for qualifications;

3) the awarding and recognition of joint degrees, including at the doctorate level; and

4) creating opportunities for flexible learning paths in higher education, including procedures for the recognition of prior learning. ${ }^{40}$

The Bologna Process participants also have agreed that their working group should prepare "comparable data on the mobility of staff and students as well as on the social and economic situation of students in participating countries as a basis for future stocktaking and reporting in time for the next Ministerial Conference." ${ }^{11}$

All signs indicate that the Bologna Process is likely to lead to additional changes in European higher education. There have been a number of conferences related to Bologna Process topics since the 2005 Bergen Ministerial meeting. ${ }^{42}$ The 2005-2007 Work Programme shows that a number of ambitious projects are underway. ${ }^{43}$

In sum, the Bologna Process is a new development that has gained tremendous momentum in a relatively short time. In less than a decade, it has grown from four members, all of whom were EU Member States, to forty-five members, almost half of whom are not EU Member States. Its goals have expanded significantly over the

\footnotetext{
39 ENQA is the acronym for the European Association for Quality Assurance in Higher Education. See ENQA, About ENQA, http://www.enqa.eu/. The report referred to here is ENQA, Standards and Guidelines for Quality Assurance in the European Higher Education Area (2005), http://www.bolognabergen2005.no/Docs/00-Main_doc/050221_ENQA_report.pdf.

40 See Bergen Communiqué, supra note 4, at 5 ("We expect stocktaking to be based on the appropriate methodology and to continue in the fields of the degree system, quality assurance and recognition of degrees and study periods, and by 2007 we will have largely completed the implementation of these three intermediate priorities. In particular, we shall look for progress in [the four listed items]." ).
}

$41 \mathrm{Id}$.

42 See Bologna Secretariat Website, http: / / www.dfes.gov.uk/bologna/index.cfm?fuseaction=events.list (last visited July 4, 2006).

43 The Bologna Process ministers issued a document in November 2005 that memorialized their October 2005 agreement regarding the proposed work plan. UK Secretariat, Bologna Process, BFUG WORK $\begin{array}{llll}\text { PROGRAMME } & - & 2005-2007 & \text { (Nov. }\end{array}$ http:/ / www.dfes.gov.uk/bologna/uploads/documents/WORKPROGversforweb18Nov05.doc. The Bologna Secretariat has issued several updated versions of this work program. At the time this article was written, the current version was dated August 2006. UK Secretariat, Bologna Process, BFUG Work

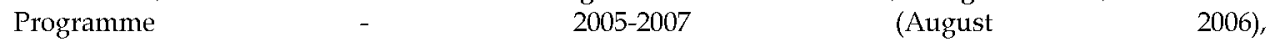
http:/ / www.dfes.gov.uk/bologna/uploads/documents/Work_Programme_at5Sept2006.doc [hereinafter August 2006 Work Program] (last visited Sept. 25, 2006). 
past eight years. As the 2005 Stocktaking Report reveals, the Bologna Process already has had a significant effect on both German higher education and European higher education.

\section{German Legal Education}

Given the ambitious scope of the Bologna Process, it probably is not too surprising to learn that implementation has not always gone smoothly within the Bologna Process countries. German legal education is an example of a situation in which implementation has proved problematic.

In order to understand some of the concerns about implementing the Bologna Process into German legal education, it is useful to consider the context in which such implementation must take place. This context includes: 1) the higher education system in Germany, including legal education; 2) the ongoing German higher educational reforms; 3) lawyer qualification rules in Germany; 4) the 2003 German reforms to legal education and lawyer qualification laws; and, 5) the debates about implementing the Bologna Process bachelor-master reforms into German legal education. Each of these points is briefly addressed below.

As a starting point, it is useful to identify the university and regulatory structure in which German legal education operates. German legal education is not a postgraduate program as it is in the U.S., but is instead taught at the undergraduate level by a department within a higher education institution. ${ }^{44}$ German universities, and thus German legal education, are subject to both state and federal regulation. ${ }^{45}$

\footnotetext{
44 See, e.g., CCBE, Comparative Table on Training of Lawyers in Europe, at Q. 4, pp. 23-26 and 30 (Sept. 2005), available at http://www.ccbe.org/doc/En/comparative_table_en.pdf [hereinafter CCBE Survey] (showing that in Europe, including Germany, law typically is taught as an undergraduate course of study in the universities). For information on the different kinds of German higher education institutions, see infra note 50 and accompanying text.

45 The primary federal law that applies to German higher education institutions, see Hochschulrahmengesetz (HRG - Framework Act for Higher Education) Jan. 19, 1999, BGBl. I at 18, last amended by Act, Dec. 27, 2004, BGB1. I at 3835, art. 1 [hereinafter 1998 Federal Framework Act] (considering the decision of the Bundesverfassungsgericht (BVerfG - Federal Constitutional Court), 2 BvF 1/03, Jan. 26, 2005, http://www.bmbf.de/pub/hrg_20050126_e.pdf.). An example of a state law regarding higher education is Gesetzes über die Hochschulen des Landes Nordrhein-Westfalen (HG Hochschulgesetz [Law of Higher Education Institutions in Nordrhein-Westfalen], Mar. 14, 2000 , GV. NRW. at 190, last amended by Act, November 30, 2004, GV. NRW. at 752, http://www.innovation.nrw.de/hochschulen_in_nrw/recht/HG.html (last visited July 1, 2006). But see infra note 46 regarding the recent federalism reforms.
} 
The scope of such federalism has been the subject of recent debates and legislative reform. 46

A second contextual point is that the Bologna Process reforms are just one of several sets of major reforms facing German higher education institutions, all of which have required higher education institutions' attention and have tested their adaptability. ${ }^{47}$ These major reforms include the introduction of tuition, the ability of universities to select their own students to a limited degree, the federal government's "Excellence Initiative," which provides recognition and significant additional federal money to selected German universities, and the introduction of the "Junior Professor" program. 48

46 In October 2003, the Bundestag and the Bundesrat created a Joint Commission that was charged with the "modernization of the federal system." See Bundesrat, Föderalismusreform, http://WwW.bundesrat.de/cln 051/nn 6906/DE/foederalismus/Foederalismus-

inhalthtml nnn=true [hereinafter Federalism Reform Website]. In June 2006, the government presented a draft federalism reform bill, which was adopted on July 7, 2006 and took effect in September 2006. Background information, drafts and the final legislation is available at the Federalism Reform Website, supra. These reforms were adopted after this article was drafted and are beyond the scope of this article. Prior to the adoption of these reforms, the German Ministry for Education and Research had explained as follows the implications of this federalism reform for higher education:

\begin{abstract}
The most important key to innovation is an education and research system that is oriented to today's challenges and that is truly world-class. Germany needs to become faster, better and especially - more international! To achieve these aims, we have to shed bureaucratic ballast, divide responsibilities more clearly and streamline and clarify decision-making structures. Herein lies the real opportunity afforded by the reform of the federal system.
\end{abstract}

German Federal Ministry of Education and Research, Using the opportunities provided by the reform of Germany's federal system, http:/ / www.bmbf.de/en/1263.php (last visited June 11, 2006).

47 Many of the Bologna reforms, including the switch to bachelor and master's degrees and an "evaluation" requirement, were contained in the 1998 Federal Framework Act, supra note 45. For information in English about all of these reforms, including the Bologna Process reforms, see German Federal Ministry of Education and Research, Higher Education Reform, at http://www.bmbf.de/en/655.php [hereinafter Higher Education Reform Webpage]. See also Terry, The Bologna Process: A German Case Study, supra note 2, at \$I(B)(2).

${ }^{48}$ See Higher Education Reform Webpage, supra note 47. This webpage includes links to pages discussing each of these reforms except the tuition reform. This webpage includes a link to the BAföG, which provides financial assistance to students, but does not directly address the tuition reforms. For a German webpage listing the status of student fees in each German state, see freier zusammenschluss von studentInnenschaften (fzs), Themen: Studiengebühren: überblick bundesländer, http://www.fzs.de/themen/studiengebuehren/bundeslaender/index.html (last visited June 19, 2006). 
The existing lawyer qualification system is another important aspect of the context in which Bologna Process implementation occurs. ${ }^{49}$ In order to qualify as a lawyer in Germany, students must successfully complete their legal studies at a university, rather than a Fachhochschule (University of Applied Sciences).$^{50}$ After completing law studies at a university, a student who is interested in becoming a licensed lawyer or a judge will take the first Staatsexamen (State Examination), which consists of both written and oral exam questions.51 After successfully completing these exams, a student will begin a two year practical training period known as the Referendariat (Internship). ${ }^{52}$ After completing this training, the student is eligible to sit for the second Staatsexamen, which again consists of both written and oral exam questions. ${ }^{53}$ If the student successfully passes this second set of exams, he or she may register as a licensed lawyer or is eligible to be hired as a judge. ${ }^{54}$

With respect to this lawyer qualification system, it is important to understand that traditionally, students who successfully completed law studies at the university did not receive an academic degree but would instead point to the Staatsexamen as

49 For additional information about qualifying as a lawyer, see Jutta Brunee, The Reform of Legal Education in Germany: The Never-Ending Story and European Integration, 42 JOURNAL OF LEGAL EDUCATION 399 (1992); Philip Leith, Legal Education in Germany: Becoming a Lawyer, Judge, and Professor, 4 WEB JOURNAL OF CURRENT LEGAL ISSUES (1995), http://webjcli.ncl.ac.uk/articles4/leith4.html; Annette Keilmann, The Einheitsjurist: A German Phenomenon, 7 GERMAN LAW JOURNAL 293 (2006), http://www.germanlawjournal.com/article.php?id=712 [hereinafter Keilmann]; Terry, The Bologna Process: A German Case Study, supra note 2, at $\$ \mathrm{I}(\mathrm{C})$.

इ0 Germany has three types of higher education institutions: 1) universities; 2) Fachlochschule (UAS -Universities of Applied Sciences), and 3) colleges of art and music. See HRK- the German Rectors Conference, National Higher Education System: Germany, http://www.hrk.de/eng/download/dateien/NatStatem_GER(1).pdf [hereinafter National Higher Education System: Germany].

The lawyer qualification requirements are set forth in federal and state laws. Deutsches Richtergesetz (DriG - The German Judiciary Act) Apr. 19, 1972, BGBl. I at S. 713; last amended through Article 27 of the Act of April 19, 2006 (BGB1. I S. 866), available at http://bundesrecht.juris.de/drig/[hereinafter $\mathrm{DRiG]}$. In order to qualify as a lawyer, one must attend a university. $I d$. at $\$ \$ 5$ and $5 \mathrm{a}$.

$\bar{s} 1$ d. at $\S 5 \mathrm{~d}$.

$52 I d$. at $\$ 5 \mathrm{~b}$.

$53 I d$. at $\$ \$ 5$ and $5 \mathrm{~d}$.

54 Id. at $\$ 5$ (access for judges); Bundesrechtsanwaltsordnung- BRAO, $\$ 4$ (as amended Dec. 21, 2004), available at http://bundesrecht.juris.de/bundesrecht/brao/index.html (last visited Nov. 15, 2005)(access for lawyers). An earlier, outdated English version of the BRAO is available at http://www.brak.de/seiten/pdf/Berufsregeln/brao_engl.pdf (last visited Nov. 15, 2005)(version from June 11, 2002). 
proof that they successfully completed their university law studies. ${ }^{55}$ The corollary is that students who successfully studied law at the university but did not take the Staatsexamen did not receive a concrete degree to show for their efforts. However, this situation recently has changed as Germany's Länder (states) have amended their laws to allow universities to award a degree called the Diplom-Jurist degree to law students who successfully complete their university law studies and the first set of state exams. ${ }^{56}$ Many universities have taken advantage of this change in the law and now award such Diplom-Jurist degrees.57

The fourth important background point concerns the recent reforms to German legal education. In order to understand the debates about implementing the Bologna Process into German legal education, it is important to know that in 2003, Germany adopted legal education reforms that have been called the most sweeping in a century. ${ }^{58}$ Among other things, these reforms require university students to select an area of specialization, learn certain "soft skills," such as rhetoric, and obtain foreign language skills. The reforms also specify that students' university

55 See, e.g., National Higher Education System: Germany, supra note 50, at 1 (explaining that traditionally, study led to the Diplom or Magister Artium degrees or completion of the state examination.) Although German states for many years had the power to create a Diplom Jurist degree, few did so. Compare $\$ 18$ of the 1976 version of the federal education law, which allowed German states to authorize the degree of Diplom to law graduates who successfully passed the state examinations and the late adoption of this option by some German states. See Hochschulrahmengesetz (HRG) [Framework Act for Higher Education], Jan. 26, 1976, version applicable from Jan. 30, 1976, to Nov. 22, 1985, BGBl I 1976, 185, available at http:/ / www.gesetze-im-internet.de/bundesrecht/hrg/gesamt.pdf (last visited March 16, 2006); infra note 56 (NRW's recent authorization of the Diplom Jurist degree).

${ }^{5}$ S See, e.g., Gesetz über die Hochschulen des Landes Nordrhein-Westfalen (Hochschulgesetz - HG) [Higher Education Law of Nordrhein-Westfalen], March 14, GV. NRW. at 190, zuletzt geändert durch Gesetz December 16, 2003, GV. NRW. at 772, at \$\$ 2(4) and 96(2), available at http://sgv.im.nrw.de/gv/frei/ 2000/Ausg13/AGV13-1.pdf\#search=\%22NRW\%20

(Hochschulgesetz\%20\%E2\%80\%93\%20HG)\%20vom\%2014\%20M\%C3\% A4rz\%202000\%22 (NordrheinWestfalen law authorizing the Diplom degree for those who successfully passed the state examinations in law). See also Terry, The Bologna Process: A German Case Study, supra note 2, at §I(C).

57 See, e.g., University of Cologne Faculty of Law, Ordnung zur Verleihung des Hochschulgrades "Diplom-Juristin" oder "Diplom-Jurist" (October 1, 2004), available at http://www.uni-koeln.de/jurfak/www/_download/diplomjurist_20010813.pdf. (University of Cologne Faculty of Law regulation adopted pursuant to the NRW law, supra note 56; this faculty rule authorizes, for the first time, the award of the Diplom-Jurist degree for those who successfully pass the first state examination and retroactively grants it to those graduates who passed their first state examination after January 1, 1980); accord Marc-André Delp, Ein heißer Tipp: Diplom-Jurist in Niedersachsen, Online JuMagazine, May 22, 2002, http://www.jumag.de/ju4302.htm (noting that the degree of Diplont-Jurist is now available at the universities of Hannover, Osnabruck and Göttingen).

58 Peter M. Huber, Der Bologna-Prozess und seine Bedeutung für die deutsche Juristenausbildung, 1 EUROPEAN JOURNAL OF LEGAL EDUCATION 35 (2004), available at http://www.jura.uni-muenchen.de / einrichtungen/fakultaetentag/aktuell/vortragelfa.pdf. 
performance should count as 30\% of their weighted score on the first Staatsexamen and require students to spend more time in a lawyer's office during their Referendariat training period. ${ }^{9}$

Finally, it is important to know that there has been tremendous discussion in Germany about the wisdom of implementing the bachelor-master degree aspect of the Bologna Process into German legal education. Although important stakeholders have endorsed the application of the Bologna Process to German legal education, ${ }^{60}$ both the federal Minister of Justice and the organization of state justice ministers (JUMIKO) have strongly opposed implementing certain aspects of the Bologna Process. ${ }^{61}$ Although there has been some support from individual German

59 Gesetz zur Reform der Juristenausbildung (Law on the Reform of Legal Education), July 11, 2002, BGBl. I, 2002, Teil I Nr. 48, 2592 et seq., available at http://217.160.60.235/BGBL/bgbl1f/bgbl102s2592.pdf [hereinafter 2003 German Legal Education Reforms]. This law revised the provisions of the DRiG, supra note 50. For commentary in English about these revisions, see Matthias Kilian, Developments in the German Legal Profession in 2003, available at http:/ / www.uni-koeln.de/jur-fak/dzeuanwr/germanlegalprofession2003.pdf; Keilmann, supra note 49, at 297-299. For a discussion of proposed reforms that were not adopted, see id. at 305-06.

${ }^{60}$ The stakeholders that have endorsed the Bologna Process' application to legal education include the German Ministry of Education and Research in its submissions to other Bologna Process countries, the organization of higher education institutions called the Hochschulrektorenkonferenz or HRK, which coauthored Germany's national report, and the Wissenschaftsrat (the Science Council that advises the government). See, e.g., Sekretariat der Ständigen Konferenz der Kultusminister der Länder in der Bundesrepublik Deutschland and Bundesministerium fur Bildung und Forschung (BMBF), Germany's National Report 2004: Achieving Bologna Process Objectioes A Joint Report by KMK and BMBF at p. 18, available at http://www.bologna-bergen2005.no/Docs/Germany/National_Reports-Germay_050118orig.PDF [hereafter 2004 German National Report] (" The switch to the two-cycle system is to continue and availability of accredited Bachelors and Masters degrees will be expanded. The ongoing aim is to integrate further state examined degree programmes like law, medicine and pharmacy into the twocycle system. ..."); Wissenschaftsrat, Empfehlung zur Reform der staatlichen Abschlüisse (Nov. 15, 2002), available at http://www.wissenschaftsrat.de/texte/5460-02.pdf. [hereafter Wissenschaftsrat Study]. For additional information, see Terry, The Bologna Process: A German Case Study, supra note 2, at \$III(B).

61 See, e.g.r Justizministerkonferenz, Herbstkonferenz der Justizministerinnen und Justizminister am 17.11.2005, Beschlüsse der Justizministerkonferenzen 1, Der Bologna-Prozess und seine möglichen Auswirkungen auf die Juristenausbildung, at $\uparrow 3$, available at http://www.justiz.bayern.de/imperia/md/content/stmj_internet/ministerium/ministerium/jumiko /2005/htop_i1.pdf (last visited Nov. 25, 2005)(, Die Justizministerinnen und Justizminister sind der Überzeugung, dass die mit einer Übernahme der Ziele der Bologna-Erklärung notwendig werdende Neustrukturierung des volljuristischen Studiums derzeit nicht sinnvoll ist. Sie ist ohne eine Auswertung der Ergebnisse der gerade erst begonnenen Umsetzung des Gesetzes zur Reform der Juristenausbildung auch nicht vertretbar.")[hereinafter JUMIKO November 2005 Resolution]; Impulsreferat der Bundesministerin der Justiz Frau Brigitte Zypries zum Thema "Reform nach der Reform - Vereinbarkeit der besonderen Wesenszüge der Juristenausbildung in Deutschland mit dem Anliegen des BolognaProzesses", available at http://www.jura.unimuenchen.de/einrichtungen/fakultaetentag/aktuell/referate/zypries.pdf; Beate Merk, Der BolognaProzess -Juristische Staatsprüfung oder Bachelor?, Forschung \& Lehre 322 (June 2004). 
lawyers, most law-related organizations have opposed the switch to a bachelormaster degree system or the idea of allowing students who receive a bachelor degree to qualify as lawyers. ${ }^{62}$ For example, the bachelor-master issue dominated the discussion at the September 2005 Berlin Symposium entitled The Bologna Process and German Legal Education. ${ }^{63}$ This conference resulted in a joint press release by the three sponsoring organizations: the Deutscher Anwaltverein (German Bar Association--DAV), Deutscher Juristen-Fakultätentag (German Law Faculties Association-DJFT), and Deutscher Hochschulverband (German Association of Higher Education); this press release stated that a bachelor's degree should not be sufficient to qualify one to become a lawyer. ${ }^{64}$

In November 2005, probably as a result of the strong opposition to the bachelormaster Bologna Process reforms, the Grand Coalition German government included in its coalition contract a section related to legal education and the Bologna Process. ${ }^{65}$ This section indicates that the Government will not change the

Recently, however, there appeared to be some thawing of this position. The Justice Minister from the German state of Nordrhein-Westfalen gave a speech to the Bundesrechtsanwaltskammer (BRAK) in which she encouraged the BRAK to embrace the Bologna Process. See Vortrag von Justizministerin Roswitha Müller-Piepenkötter anlässlich der 109. Hauptversammlung der BRAK in Münster "Neuregelungen des Rechtsberatungsrechts und Bachelor- und Masterstudiengänge für Juristen", 15.09.2006, available at http://www.justiz.nrw.de/Presse/reden/15_09_061/index.php.

62 See infra note 63. For additional information, see Terry, supra note 2, at $\$ I I I$ (citing the reactions of the Bundesrechtsanwaltskammer (BRAK) and the Deutscher Anwaltverein (DAV), which have expressed concerns and contrasting that with the views of commentators such as Professor Hein Kötz and Dr. Jens Jeep, among others, who have been supportive of implementing Bologna Process changes).

${ }_{63} 3$ Symposium: Der Bologna-Prozess und die Juristenausbildung in Deutschland Sept. 22, 2005, Berlin, available at http://www.hochschulverband.de/cms/fileadmin/pdf/seminare/Faltblatt.pdf [hereinafter Berlin Symposium].

64 Deutscher Anwaltverein, Deutscher Juristen-Fakultätentag, Deutscher Hochschulverband, Presseinformation Nr. 14/2005: Bachelor qualifiziert nicht für Beruf des Richters oder Anwalts (Sept. 22, 2005), available at http:/ / www.hochschulverband.de/cms/fileadmin/pdf/pm/pm14-2005.pdf.

The day after this press release, the HRK or German university association issued its own press release that was critical of the Symposium press release. Hochschulrektorenkonferenz, Pressemitteilung 54/05: Gezielte Fehlinformationen gefährden die bereits laufenden Bemühungen im Bologna-Prozess. HRK reagiert auf Darstellungen in der Presse zum Bachelor in Jura und Medizin, available at http://www.hrk.de/95_2802.php.

${ }_{65}$ Gemeinsam für Deutschland - mit Mut und Menschlichkeit, Koalitionsvertrag zwischen CDU, CSU und SPD 144-145 (Nov. 11, 2005), avaliable at http://www.spd.de/servlet/PB/show/1589444/111105_Koalitionsvertrag.pdf (last visited Nov. 29, 2005). 
qualification requirements for lawyers and will not allow those with only a bachelor's degree to qualify as a lawyer. ${ }^{66}$

\title{
D. Reflections and Recommendations from a U.S. Perspective
}

With this contextual background, I now turn to my reflections and recommendations regarding German legal education and the Bologna Process reforms. Making recommendations about another country's legal system is, of course, fraught with risk since it is difficult for an outsider to truly understand another system and culture. On the other hand, the insights of outsiders sometimes can prove useful because of the distance and perspective they bring to the issues.

\section{German Legal Education Cannot Avoid the Impact of the Bologna Process}

My first observation about the Bologna Process and German legal education is that it seems unlikely that German legal education will be able to resist for long the pressures to comply with the Bologna Process. There are a number of different factors that will place pressure on German legal education to implement the Bologna Process objectives. For example, in the future, German law faculties likely will face pressure from within their own universities. ${ }^{67}$ If all German university departments except the law faculty are required to comply with the Bologna Process, regardless of their preferences, these other departments and faculty members may not be particularly sympathetic to the law faculty's assertions about the difficulties that would result from Bologna Process implementation. 68

66 $I d$. This contract is not completely clear about whether it rejects the application of the entire Bologna Process to legal education or whether the intent is to reject only the bachelor-master degree reforms. For additional information on this topic, see Terry, The Bologna Process and Legal Education, supra note 2, at \&III(C). The Grand Coalition contract states:

\begin{abstract}
Mit einer Reform der Rechtsberatung werden wir weiter die Qualität der anwaltlichen Beratung sichern. Wir schützen die Verbraucherinnen und Verbraucher vor unqualifiziertem Rechtsrat ... Die Juristenausbildung muss den sich ändernden Anforderungen an die juristischen Berufe gerecht werden. Einen Bedarf für neue Abschlüsse gibt es allerdings nicht. Die Koalitionspartner lehnen deshalb die Übertragung des „Bologna-Prozesses" auf die Juristenausbildung ab.
\end{abstract}

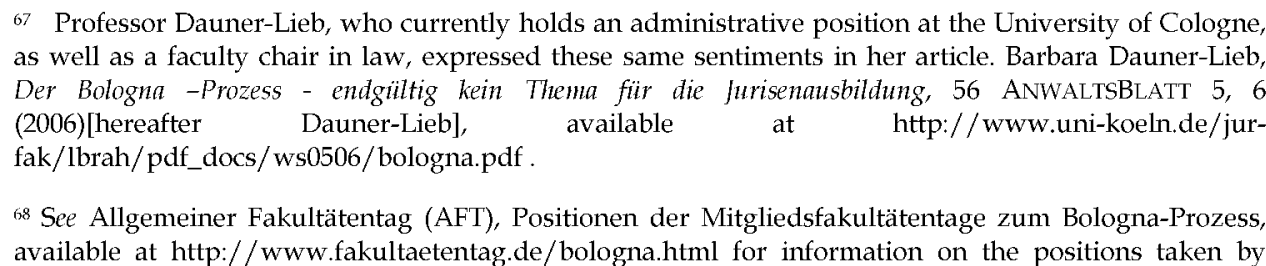


Moreover, the law faculty's failure to implement the Bologna Process objectives could cause logistical difficulties within a university because some students study law as a minor or are engaged in interdisciplinary studies. ${ }^{69}$

A second source of pressure could come from the German legal community. The existing comparative legal education data might make some German lawyers worry that if German legal education does not adopt the Bologna Process reforms, it will become isolated within Europe. For example, in September 2005, the Council of Bars and Law Societies of Europe (CCBE), which is the officially recognized representative organization for the legal profession in the EU, published a lengthy report that summarized the information it had obtained from its member bars regarding lawyer training. ${ }^{70}$ Some of the data in this report addressed Bologna Process implementation issues and showed that many European countries have revised their legal education systems in light of the Bologna Process. According to the CCBE data, the Bologna Process has affected the law degree structure in fifteen of the thirty-seven jurisdictions it surveyed. ${ }^{71}$ The data also shows that fourteen of thirty-seven jurisdictions now use ECTS for crediting purposes and seven use it for grading purposes.72 If the CCBE's data is correct and if law faculties elsewhere in

subject-matter area faculty organizations,. This list is not complete, however, it does not include the position of the Deutschen Juristen-Fakultätentages (DJFT). See also Terry, The Bologna Process and Legal Education, supra note 2, at \$II(B).

69 See, e.g., University of Cologne Faculty of Law, Rechtswissenschaftliche Studiengänge, available at http://www.uni-koeln.de/jur-fak/www/studium/studiengaenge/ (describing the requirements for student who study law as a minor or "Nebenfach").

70 See CCBE Survey, supra note 44 . The CCBE is the officially recognized representative organization for the legal profession in the EU and represents more than 700,000 lawyers. The CCBE consists of 28 delegations whose Members are nominated by regulatory bodies of the Bars and Law Societies in the 25 Member States and the 3 member countries of the European Economic Area. CCBE, What is the CCBE?, available at http://www.ccbe.org/en/accueil/accueil_en.htm. See also Laurel S. Terry, An Introduction to the European Conmunity's Legal Ethics Code Part I: An Analysis of the CCBE Code of Conduct, 7 GEORGETOWN JOURNAL OF LEGAL ETHICS 1 (1993), available at http:/ / papers.ssrn.com/sol3/papers.cfm?abstract_id=596203.

71 See CCBE Survey, supra note 44, at Question 5a, pp. 26-29. Although the responses are not completely unambiguous, I concluded that the following countries provided an affirmative response to the question of whether the Bologna Process had affected their degree structure: Belgium; Estonia; Finland; France; Iceland; Italy; Latvia; Luxembourg; the Netherlands; Norway; Poland; Slovak Republic; Spain; Croatia; and Switzerland. (Some of these countries indicated that changes had been made which would take effect at a specified future date.) Only ten countries provided a negative response to this question, with ten countries providing an answer that was conditional, non-responsive or stated that the question was inapplicable. Id.

72 See CCBE Survey, supra note 44, at Question 8, pp. 74-77. Although the responses are not completely unambiguous, I concluded that the following seven countries provided an affirmative response to the question of using ECTS for grading purposes were: Belgium; the Netherlands; Norway; Slovak 
Europe are implementing the Bologna Process, then German legal educators may have a difficult time convincing skeptics that German legal education should be exempt from the Bologna Process.

A third source of pressure could come from the German government. The use of color-coded "grades" in the 2005 Stocktaking Report (and the likely continuation of that methodology in the 2007 Stocktaking Report) places a certain amount of pressure on countries to conform to these benchmarks. This concept has been documented by scholars in different disciplines who sometimes articulate this principle by noting that "what gets measured matters."73 For various reasons, including national pride and the need to compete within Europe and worldwide for human and non-human resources, it is likely that most countries will not want to receive a Bologna Process Stocktaking Report grade of "red" or "insufficient" when compared to their peers, regardless of the issue being reviewed. Thus, because the German government may want favorable ratings in future stocktaking exercises, it may place financial and other pressure on universities to comply with the Bologna Process benchmarks. This in turn is likely to create pressure on university law departments to implement the Bologna Process objectives.

Some have suggested that the German government is unlikely to require changes in legal education because the German Ministry of Justice has more domestic political power than the German Ministry of Education. Although this may be true in general, it appears that the German Ministry of Education has more power than the Ministry of Justice with respect to the implementation of the Bologna Process. For

Republic; Sweden; Northern Ireland; and Croatia. I treated the Czech Republic answer as conditional because $I$ interpreted the qualification about which university as applying to this question also. I also treated the Spanish answer as conditional since it stated that the credits are not yet equivalent to the ECTS. The fourteen jurisdictions that I treated as providing unconditional "yes" response to the question of using ECTS for crediting purposes were: Austria; Belgium; Finland; France; Hungary; Italy; the Netherlands; Norway; Slovak Republic; Sweden; Northern Ireland; Scotland; Croatia; and Switzerland. Only two countries provided an unequivocal "no" answer to the question of whether ECTS was used for crediting, with eleven countries providing a "no" answer to the question of whether ECTS was used for grading purposes. $l d$.

${ }^{73}$ A number of commentators have made this observation including Tom Peters, who said "What gets measured gets done." A Google search of the phrase "what gets measured matters" shows that this concept is used in a wide variety of disciplines and countries, ranging from the Statistician-General of South Africa to human resource managers at companies to conference presenters for the National Criminal Justice Reference Service, which is a program administered by the U.S. Department of Justice to the Texas state government Workforce initiative." The principle that what gets measured matters is supported by significant social science research. See, e.g., DAVID OSBOURNE AND TED GAEBLER, REINVENTING GOVERNMENT (1992); but see R.D. Behn, Why measure performance? Different purposes require different measures, 63 PUBLIC ADMINISTRATION REVIEW 586 (2003) (noting that the public sector has special factors that complicate the causal link between measuring and performance). 
example, the German Ministry of Education is responsible for many of the representations made to other Bologna Process countries. ${ }^{74}$ In addition, the German Ministry of Education has devoted numerous resources to implementing the Bologna Process and has put in motion conferences, research papers and other items that make implementation more likely. ${ }^{75}$ In this respect, the German Ministry of Education appears fully supportive of implementing the Bologna Process objectives. ${ }^{76}$ Finally, even if it had the authority to do so, it is not clear that the Ministry of Justice would be willing to oppose the Ministry of Education on issues related to the Bologna Process and German legal education. Recent actions by that the Ministry of Justice suggest that it may not be as sympathetic now as it was previously to the argument that lawyers and legal education are "different" and therefore require special treatment. ${ }^{77}$ The recent report of the independent Monopoly Commission provides additional support for the idea that German lawyers may encounter resistance to the idea that they are "different" and should be exempt from the Bologna Process. Among other things, this recent report recommended that in the revised lawyer monopoly law, bachelor of law graduates be added to the list of professions who are permitted to undertake certain kinds of law-related activities. ${ }^{78}$ Thus, notwithstanding the German Grand Coalition

\footnotetext{
$7_{4}$ See, e.g., Sekretariat der Ständigen Konferenz der Kultusminister der Länder in der Bundesrepublik Deutschland and Bundesministerium für Bildung und Forschung (BMBF), Germany's National Report 2004: Achieving Bologna Process Objectives A Joint Report by KMK and BMBF at 4, available at http://www.bologna-bergen2005.no/Docs/Germany/National_Reports-Germay_050118-orig.PDF (last visited Nov. 17, 2005)[hereinafter German National Report 2004].
}

75 See, e.g., the resources listed on the German government's English-language Bologna website. German Federal Ministry of Education and Research, Bologna Process, available at http://www.bmbf.de/en/3336.php (last visited June 8, 2006). Additional information about German initiatives, including those supported by the German government, is available in German on the Bologna Webpage sponsored by the organization of German higher education institutions. See Hochschulrektorenkonferenz (HRK), Willkommen auf der Internetseite der Service-Stelle Bologna der Hochschulrektorenkonferenz, available at http://www.hrk-bologna.de/.

76 See, e.g., supra note 37 (German government press release following the 2005 Bologna Process Stocktaking Report); 2004 German National Report, supra note 74.

77 See, e.g., Diskussionsentwurf des Bundesministeriums der Justiz Entwurf eines Gesetzes zur Neuregelung des Rechtsberatungsrechts, (Rechtsdienstleistungsgesetz - RDG), available at http:/ / www.anwaltverein.de/Rechtsberatungsgesetz/gesetzentwurf.pdf (last visited June 8, 2006)(Ministry of Justice issued a draft law that would narrow the lawyer's monopoly and allow others to do activities formerly reserved to lawyers); Deutscher Anwalt Verein, Pressentitteilung 15/05, vom 31. März 2005: Ohne Anwälte keine unfassende Rechtsberatung - DAV zur Reform des Rechtsberatungsrechtes, available at http://www.anwaltverein.de/03/02/2005/15-05.html (last visited June 8, 2006) (commenting on the draft law).

78 See, e.g., Monopolkommission, Pressemitteilung (Bonn, 5. Juli 2006), availble at http://www.monopolkommission.de/haupt_16/presse_h16.pdf (last visited July 9, 2006); Monopolkommission, Mehr Wettbewerb auch im Dienstleistungssektor! Sechzelntes Hauptgutachten der 
Government Contract, it is quite possible that the German government will place pressure on German universities and their law faculties to implement the Bologna objectives and benchmarks. Finally, if globalization contributes to structural or policy convergence or institutional isomorphism, as some scholars have posited, this phenomenon may result in German law faculties conforming to the Bologna Process. ${ }^{79}$

For all of these reasons, my first point of reflection about the Bologna Process and German legal education is that it is likely that in the long term, German legal education will not be able to avoid the impact of the Bologna Process.

\title{
II. The German Legal Profession Has Neglected Some of the Bologna Priority Items
}

My second point of reflection builds on my first observation. Because it is unlikely that, in the long term, German legal education can avoid the impact of the Bologna Process, it is unfortunate that the German legal education community has not been fully engaged in discussions of all of the Bologna Process priority objectives and

Monopolkommission genäß $\S 44$ Abs. 1 Satz 1 GWB, 2004/2005, at Chapter VI, $\uparrow 1032$, available at http://www.monopolkommission.de/haupt_16/kapitel06_h16.pdf (last visited July 9, 2006). On this point, the Commission stated:

\begin{abstract}
Eine Erlaubnis zur außergerichtlichen Rechtsberatung kann aber nicht auf Diplom-Wirtschaftsjuristen beschränkt bleiben. Die Monopolkommission spricht sich deshalb dafür aus, auch Juristen mit erster Prüfung (erstem Staatsexamen) zur außergerichtlichen Rechtsberatung zuzulassen. Sollte es auch bei den juristischen Studiengängen $z u$ einer Einführung des Bachelor/Master-Modells kommen, sollte die Erlaubnis zur außergerichtlichen Rechtsberatung bereits nach dem BachelorAbschluss einsetzen - möglicherweise verbunden mit der Anforderung eines Nachweises von praktischer Tätigkeit. Denn nur so kann die Anforderung des Bologna-Prozesses, dass bereits der Bachelor eine Berufsqualifikation vermittelt, erfüllt werden.
\end{abstract}

Id. The German Monopoly Commission is an independent body that is authorized by law to recommend legislative changes to the German government every two years. See Monopolkommission, Aufgaben, available at http://www.monopolkommission.de/index.html (last visited July 10, 2006). These recommendations follow in the wake of similar recommendations in the EU and in the United Kingdom. See European Commission, DG Competition, Competition Policy and Liberal Professions, available at http:/ /ec.europa.eu/comm/competition/liberalization/conference/libprofconference.html (last visited June 8, 2006); United Kingdom Department for Constitutional Affairs, Legal Services Reform, available at http:/ / www.dca.gov.uk/legalsys/Isreform.htm (last visited July 9, 2006).

79 See, e.g., Tanja A. Börzel and Thomas Risse, When Europe Hits Home: Europeanization and Domestic Change, 4 EUROPEAN INTEGRATION ONLINE PAPERS (2000) $\mathrm{N}^{\circ}$ 15, http://eiop.or.at/eiop/texte/2000015a.htm (citing convergence theories). 
action lines. As noted earlier, there are ten Bologna Process action lines, three priority objectives for 2005, and additional priority items for 2007.80

Although the German legal profession has extensively discussed the first of the three 2005 priority objectives (the bachelor-master degree), ${ }^{81}$ it has not paid nearly as much attention to the second and third priority objectives or to the other Bologna Process action lines. These priority objectives have the potential to significantly affect German legal education and deserve more attention than they have received. As a result, I recommend that the German legal education community explicitly discuss all of the Bologna Process objectives and the benchmarks they use. It is true that the discussion surrounding the 2003 German Legal Education reforms referred to issues of quality assurance and internationalization, which implicates degree recognition. Although these Bologna Process objectives were touched upon during those debates, ${ }^{82}$ I recommend that the German legal community engage in a more focused discussion of all of the Bologna Process action lines than it has previously, and that these discussions should explicitly refer to the Bologna Process objectives and benchmarks. In the sections that follow, I elaborate on these points.

\section{The 2005 Quality Assurance Objective}

One of the 2005 Bologna priority objectives was quality assurance. When speaking about quality assurance, it is important to remember that this concept includes both evaluation and accreditation. ${ }^{83}$ The benchmarks established for the 2005 Bologna Stocktaking Report addressed both of these topics and asked whether countries had agencies responsible for quality assurance and whether their quality assurance systems included internal assessment, external review, student participation, international participation and publication of results. ${ }^{84}$ The topic of quality assurance will continue to be important in the future because it will be appraised again in the 2007 stocktaking exercise. ${ }^{85}$

\footnotetext{
${ }^{80}$ See supra notes 21 (action lines) and 23 (2005 priority objectives) and accompanying text.

${ }^{81}$ See, e.g., Berlin Symposium, supra note 63; Terry, The Bologna Process and Legal Education, supra note 2, at §III(B).

${ }^{82}$ For a discussion of the debates surrounding the 2003 reforms, see Keilmann, supra note 49 ,

83 See, e.g., HRK, The Quality Assurance Project, available at http://www.hrk.de/eng/projekte_und_initiativen/121.php (last visited June 28, 2006)(noting that one of the topics addressed by Project $Q$ is "the relationship between evaluation and accreditation.").

842005 Stocktaking Report, supra note 25, at pp. 16-17 (listing benchmarks for the quality assurance objective).

85 Bergen Communiqué, supra note 4 , at 5 .
} 
Both accreditation and evaluation are addressed in existing German laws. For example, the 1998 amendments to the German Federal Framework Act added an evaluation obligation for the first time, and a 2005 federal law created the Stiftung zur Akkreditierung von Studiengängen in Deutschland (Foundation for the Accreditation of Study Courses in Germany) that has accreditation responsibilities and supervises the Akkrediterungsrat (Accreditation Council), which approves accrediting agencies. ${ }^{86}$ Germany has taken several steps to further implement these obligations. For example, the quality assurance project known as Project Q helps institutions develop evaluations systems, and the Akkrediterungsrat has approved six accrediting agencies, which in turn have accredited hundreds of bachelor and master degree programs. ${ }^{87}$ Because there is no exemption for law departments in the Federal Framework Act or the law that created the Akkrediterungsrat, it would seem that German law departments are thus subject to these evaluation and accreditation requirements. ${ }^{88}$

In light of the Bologna Process and these requirements, I have several recommendations to the German legal education community. First, some entity should collect and publish data regarding the existing quality assurance initiatives in German law departments. Although German universities, including law departments, must perform evaluations, as of June 2006, there was no easily available public source of information that would allow a university law department to learn how other law departments have handled this obligation. ${ }^{89}$

\footnotetext{
86 See supra note 45 for the 1998 federal Framework Act (which included evaluation) and Gesetz zur Errichtung einer Stiftung "Stiftung zur Akkreditierung von Studiengängen in Deutschland" Feb. 15, 2005, in Kraft getreten am 26 Feb. 2005, available at http://www.akkreditierungsrat.de/Stiftungsgesetz_050215.pdf (last visited July 3, 2006). An English translation of this document is available at http://www.kmk.org/doc/beschl/BS_VereinbarungundGesetzAkkreditierung_englisch.pdf [hereinafter "Establishment of a Foundation for the Accreditation of Study Courses in Germany"].

87 For additional information about accreditation initiatives in Germany, see Stiftung zur Akkreditierung von Studiengängen in Deutschland, available at http:// www.akkreditierungsrat.de/; Terry, The Bologna Process and Legal Education, supra note 2, at $\$ \mathrm{I}(\mathrm{B})(2)$. For information about Project $\mathrm{Q}$ (the Quality Assurance Project) and evaluation initiatives in Germany, see HRK German Rectors' Conference, The Quality Assurance Project, available at http://www.hrk.de/eng/projekte_und_initiativen/121.php (last visited July 3, 2006).

88 See supra notes 45,86 , and 87 .

89 See Terry, The Bologna Process and Legal Education, supra note 2, at \$II(A)(2)(citing the lack of this information on the HRK, KMK, DJFT, DJT, BRAK or DAV, or the German ELSA webpages, among others). The Akkreditierungsrat lists several subject-specific accreditation organizations on its website, but it does not list any legal studies-specific accrediting agencies. Akkreditierungsrat, Akkreditierungsagenturen, available at http://www.akkreditierungsrat.de/agenturen.htm. It is worth noting, however, that one cannot always tell from the name of the accrediting agency what programs it
} 
Because there is no comparative data regarding law department quality assurance efforts, each German university or law faculty must either develop its quality assurance program independently, without the benefit of seeing how other law departments approach the issue, or collect the comparative data itself, which is a labor-intensive undertaking. If this type of information were centrally collected and publicized, university law departments would have an easy way to review the type of evaluation systems established in other universities and determine how other institutions have handled the items benchmarked in the Bologna Process Stocktaking Report, including: how internal assessment is handled at other institutions, how external review is structured, the method used to ensure the participation of students in quality assurance programs, how publication of results is handled, and how international participation occurs. One organization that might be in a good position to collect this information is the organization of German law faculties called the Deutscher Juristen-Fakultätentag (DJFT). Regardless of who collects the information, however, it is important for the data to be collected and easily accessible.

My second recommendation is that the German legal community should engage in a dialogue about the factors that it thinks a quality assurance or accreditation system should evaluate and discuss whether these factors should differ depending on the nature of the law program. For example, should the method of evaluation differ depending on whether the higher education institution awards a bachelor of law degree, a master's of law degree, or a Diplom-Jurist degree? It is important for the German legal education community to begin this dialogue sooner rather than later because higher education institutions are now beginning to implement the evaluation obligation contained in the 1998 German federal Framework Act and the Bologna Process. ${ }^{90}$ For this reason, it is regrettable that the Deutscher Juristentag cancelled its plans to sponsor a program devoted to the Bologna Process and legal education after the Grand Coalition decision to exclude certain aspects of legal education from the Bologna Process. ${ }^{91}$ If the German legal education community

has accredited. For example, FIBAA, which is the Foundation for International Business Administration Accreditation, has accredited five bachelor of law degrees and five master's of law degrees. See Table 2, infra note 102 and accompanying text.

90 See, e.g., University of Cologne, Die Bachelor-/Master-Studienreform an der Universität zu Köln , available at http://www.uni-koeln.de/uni/images/aktuell_bamareform1.jpg (last visited June 14, 2006)(noting that quality assurance is phase 3 of the University of Cologne's implementation of the Bologna Process and will begin in academic year 2006-07).

${ }^{91}$ See Email Letter from Dr. Andreas Nadler, Generalsekretär des Deutschen Juristentages e. V. to author, Jan. 16, 2006 (explains the cancellation of the program scheduled to discuss the Bologna Process; the cancelled program was not the regular biennial meeting of the DJT)(on file with author). The cancellation of this program was regrettable because the Deutscher Juristentag (DJT) provides a forum to 
wants input into the factors by which it will be evaluated, it needs to be in a position to respond to the recommendations proposed by the government, by a higher education institution, by accrediting or evaluation agencies, or by the Bologna Process Follow-Up Group. This dialogue would be easier, however, if information about the existing evaluation programs and models was readily available.

My third recommendation is that a law-related entity should collect and publish, in one accessible location, a variety of information related to the existing bachelor of law and master's of law degrees. The DJFT already collects data regarding the number of bachelor of law and master's of law degrees awarded by its members. ${ }^{92}$ It publishes on its webpage a very useful chart that includes information about type of degree awarded (bachelor or master), when the institution began offering the degree, the number of students in the degree program, the number of graduates, and the length of time it takes to receive such a degree. ${ }^{93}$ According to this DJFT chart, in February 2006, DJFT members offered eight bachelor programs. ${ }^{94}$ This chart also showed five master's degrees, two of which were offered by a single institution. ${ }^{95}$ Unfortunately, this DJFT chart does not indicate whether these bachelor of law and master's of law degrees are accredited or by whom. It would be relatively simple to add a column with this information to the existing DJFT chart, and I recommend the DJFT do so.

discuss and study important topical issues and possible legal reforms and historically, its views have been influential with the courts and legislature. Deutscher Juristentag, Der Deutsche Juristentag, available at http://www.djt.de/content.php?lang=de\&I=2 (last visited Jan. 14, 2006). The DJT has been in existence since 1860; it has approximately 8,000 members who come from all of the legal professions. Id.

92 Deutscher Juristen-Fakultätentag, Grundständige Bachelor- und Master-Studiengänge an den Juristischen Fakultäten/Fachbereichen, Stand 28. Februar 2006, http://www.jura.unimuenchen.de/einrichtungen/fakultaetentag/aktuell/uebersichtbachelor.pdf (last visited July 12, 2006)[hereinafter DJFT Degree Chart].

$93 \mathrm{Id}$.

94 Id. at 1 . This chart showed bachelor degrees offered by a total of eight institutions, six of which were traditional public university law departments. $I d$. The institutions offering these bachelor degrees included the Universities of 1) Bremen; 2) Frankfurt an der Oder; 3) Greifswald; 4) Hamburg; 5) Münster; 6) Osnabrück; and 7) Bucerius Law School and 8) Hagen Fern Universität. Conpare id. with Mitglieder des Deutschen Juristen-Fakultätentages (May 2006), available at http://www.jura.unimuenchen.de/einrichtungen/fakultaetentag/mitglieder/mitglied.htm (last visited June 13, 2006)(lists 43 members of the DJFT, which is the voluntary organization of the law faculties at German public universities, and at the (private) Bucerius Law School and the Fern Universität Hagen)[hereinafter DJFT Members].

$95 \mathrm{Id}$. According to the DJFT, the institutions offering master's of law degrees included the Universities of: 1) Bremen; 2) Frankfurt an der Oder; 3) Greifswald (which awards two master's degrees); and 4) Hamburg. Id. 
In addition to adding an accreditation column to the existing DJFT chart, it would be useful if the DJFT chart included summary data that shows how many accredited law degrees have been approved by each of the accrediting agencies approved by the Akkrediterungsrat. ${ }^{96}$ This data could help German law departments decide which accrediting agency they would prefer to use if they decide to offer an accredited law degree. ${ }^{97}$ Moreover, such a chart could serve as a useful-crosscheck for the DJFT to determine whether the information it receives from its members is accurate. ${ }^{98}$

In addition to this data, it would be useful to have some entity publish data that shows the number of bachelor of law and master's of law degrees offered by all German higher education institutions, not just DJFT members. It would also be interesting to know how many of these programs are accredited. Currently, it is difficult to determine the percentage of accredited bachelor of law and master of law degrees offered by those German universities that offer a traditional legal education program (i.e. a university program that allows students to qualify as lawyers.) It would also be interesting to know what percentage of German universities that train lawyers also offer a bachelor or master's of law degree, and how many of these degrees are accredited. Although the Hochschulrektorenkonferenz (German Rectors Conference--HRK) maintains a database that shows accredited bachelor of law and master of law programs and allows one to search according to the different kinds of higher education institutions, ${ }^{99}$ one cannot easily determine

96 The six agencies that had been accredited as of June 2006 included: 1)Agentur für Qualitätssicherung durch Akkreditierung von Studiengängen - AQAS; 2) Akkreditierungsagentur für Studiengänge der Ingenieurwissenschaften, der Informatik, der Naturwissenschaften und der Mathematik (ASIIN); 3) Akkreditierungsagentur für Studiengänge im Bereich Heilpädagogik, Pflege, Gesundheit und Soziale Arbeit e.V. (AHPGS); 4) Akkreditierungs-, Certifizierungs- und Qualitätssicherungs-Institut (ACQUIN); 5) Foundation for International Business Administration Accreditation (FIBAA); and 6) Zentrale Evaluations- und Akkreditierungsagentur Hannover (ZEvA). Akkreditierungsagenturen, available at http://www.akkreditierungsrat.de/agenturen.htm.

97 It is possible that the law department would not be given a choice by its university about which accrediting agency to use. But if the law department knew which agency it preferred, it would then be in a position to lobby its university in favor of a particular accreditation agency.

${ }^{98}$ A cross-check system could be useful because in the past, there have been some discrepancies in data. For example, in June 2006, the websites of the accrediting agencies listed master's degrees offered in Hanover, Düsseldorf and Frankfurt am Main, none of which was listed on the DJFT chart. Compare supra note 95 with infra note 109.

y9 See HRK, The guide to Degree Programmes of German Higher Education Institutions, available at http://81.169.169.236/kompass/xml/index_stud_en.htm (last visited June 24, 2006). 
from the HRK database whether the institution in question also provides the traditional German legal education that culminates in the Staatsexamen. ${ }^{100}$

The table below was prepared by this author and shows the type of data that might be useful for the DJFT or another German entity to collect. This table indicates the total number of bachelor of law programs accredited by each of the agencies approved by the Akrrediterungsrat and indicates how many of those programs are offered by the forty-one traditional public university members of the DJFT. ${ }^{101}$ This table also shows how many masters of law degrees have been approved by the designated accreditation agencies and how many of these accredited degrees are offered by the forty-one traditional public university members of the DJFT.

100 Id. Examples of universities that now offer an accredited bachelor of law program but not a Staatsexamen law degree include the Universität Kassel and the Universität Oldenburg. Id. This information is not available from a single search of the HRK database but requires two separate searches to learn whether a university that offers a bachelor of laws degree also offers the traditional legal education that allows one to take the Staatsexamen. In addition to this difficulty, the HRK database includes multiple entries for "law" and many specialties which can make it difficult to come up with consistent data.

${ }_{101}$ As of June 2006, the DJFT had forty-three members. See DJFT Members, supra note 94. Table 2 refers to forty-one traditional public university DJFT members. This group of forty-one DJFT institutions excludes the Bucerius Law School, which is a private institution and therefore not accredited by the Akkrediterungs-approved agencies, and excludes the Fern Universität Hagen because its graduates are not eligible to sit for the Staatsexamen. 
Table 2: Law Degrees Accredited by Approved Agencies (As of 6/2006): ${ }^{102}$

\begin{tabular}{|c|c|c|c|c|c|c|}
\hline  & 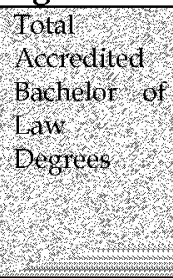 & 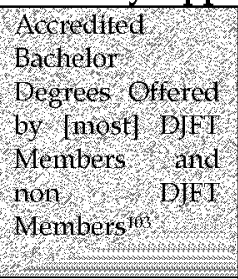 & $\begin{array}{l}\text { DIT } \\
\text { Gscinitions } \\
\text { Granting } \\
\text { Aceredited } \\
\text { Badhelor } \\
\text { Degrees }\end{array}$ & $\begin{array}{l}\text { Total } \\
\text { Aroredited } \\
\text { Master. of } \\
\text { Daw } \\
\text { Degrees }\end{array}$ & 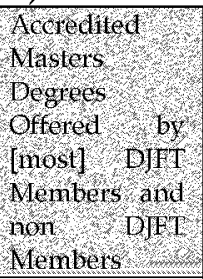 & 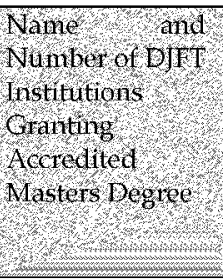 \\
\hline AQAS & 3 & $0 / 3$ & 0 & 8 & $4 / 4^{104}$ & 1 \\
\hline ASIIN & 0 & 0 & 0 & 0 & 0 & 0 \\
\hline AHPGS & 1 & $0 / 1$ & 0 & 0 & 0 & 0 \\
\hline ACQUIN & 1 & $0 / 1$ & 0 & 2 & $1 / 1$ & $1^{105}$ \\
\hline FIBAA & 5 & $0 / 5$ & 0 & 5 & $0 / 5$ & 0 \\
\hline ZEVA & 5 & $3 / 3^{106}$ & $3^{107}$ & 6 & $4 / 3^{108}$ & $4^{109}$ \\
\hline
\end{tabular}

${ }^{102}$ This Table also appears in Terry, The Bologna Process: A German Case Study, supra note 2. That article includes lengthy footnotes that identify each of the fifteen accredited bachelor of law degrees and each of the twenty-one accredited master's of law degrees.

103 As of June 2006, the DJFT had forty-three members. See DJFT Members, supra note 94. This column indicates the number of accredited bachelor degrees offered by the forty-one traditional public university institutions that are members of the Deutschen Juristen-Fakultätentages (DJFT). See supra, note 101. The DJFT institutions (other than Bucerius and Fern-Uni Hagen) offering accredited bachelor of law degrees included: 1) bachelor of law (LL.B.) at Ernst-Moritz-Arndt-Universität Greifswald (a DJFT member); 2) Comparative and European Law (LL.B.) at Universität Oldenburg / Universität Bremen (Bremen is a DJFT member but Oldenburg is not a DJFT member); and 3) Wirtschaftsrecht (LL.B.) at the Universität Osnabrück (a DJFT member). See Zentrale Evaluations-Und Akkreditierungsagentur Hannover (ZEVA), Akkreditierte Bachelorstudiengänge, available at http://www.zeva.unihannover.de/akkred/studieng/bachelor.htm (last visited June 25, 2006). For information on the nonDJFT institutions offering such degrees, see Terry, supra note 2.

${ }^{104}$ As of June 2, 2006, the Agentur für Qualitätssicherung durch Akkreditierung von Studiengängen (AQAS) had accredited eight master of law degrees, four of which were offered by a single traditional public university DJFT member - the University of Münster. See AQAS, e.v., Statistik, available at http://www.aqas.de/kategorie/statistik/ (last visited June 25, 2006) (University of Münster offers four accredited master's degrees: 1) Steuerwissenschaften ( Master of Laws); 2) Mergers and Acquisitions (Master of Laws/Executive Master of Business Administration); 3) Versicherungsrecht ( Master of Laws); 4) Real Estate Law (Master of Law) Since it is not a traditional public university DJFT member that offers the offers an education entitling one to sit for the Stantsexamen, I have not included the Bachelor of Laws offered by the FernUniversität Hagen or the Europäischer Gewerblicher Rechtsschutz (Master of Laws (LL.M.) offered by the FernUniversität in Hagen.

105 The Akkreditierungs-, Certifizierungs- und Qualitätssicherungs-Institut (ACQUIN) has accredited two master's of law programs, one of which is offered by a DJFT member. See ACQUIN, Akkreditierte Studiengänge - Master/Magister, http://www.acquin.org/acquincms/index/accred-mastloc-action (last visited June 25, 2006) (Informationsrecht - Master of Laws at the Heinrich-Heine-Universität Diisseldorf).

106 The Zentrale Evaluations-Und Akkreditierungsagentur Hannover (ZEVA) has accredited five bachelor of law programs, three of which are offered by DJFT members. See ZEVA, Akkreditierte 


\begin{tabular}{|c|c|c|c|c|c|c|}
\hline TOTAL & 15 & $\begin{array}{l}3 \text { DJF } \approx 20 \% \\
\text { 18 non DIF }\end{array}$ & $\begin{array}{l}3(6 \mathrm{f} 41) \\
-7 \%\end{array}$ & 21 &  & $\begin{array}{l}6(0 f 4) \\
\approx 15 \%\end{array}$ \\
\hline 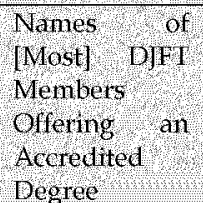 & & & $\begin{array}{l}\text { Greitswalios } \\
\text { nabruck } \\
\text { Bremen, with } \\
\text { Oldenburg. }\end{array}$ & & & 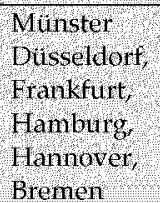 \\
\hline
\end{tabular}

As this table reveals, as of June 2006, the traditional public university DJFT institutions that offered an accredited bachelor degree in addition to the Staatsexamen included the universities in Greifswald, Osnabrück, and Bremen, the latter of which offers its degree in conjunction with the University of Oldenburg, which is not a DJFT member. 110 This means that as of June 2006, approximately seven percent of the traditional public university DJFT institutions offered an accredited bachelor of law degree.111 This table also shows that twenty percent of the accredited bachelor of law degrees were offered by the traditional university

Bachelorstudiengänge, aoailable at http://www.zeva.uni-hannover.de/akkred/studieng/bachelor.htm (last visited June 25, 2006) (1) bachelor of law (LL.B.) at Ernst-Moritz-Arndt-Universität Greifswald; 2) Comparative and European Law (LL. B.) at Universität Oldenburg / Universität Bremen(Bremen is a DJFT member but Oldenburg is not a DJFT member); and 3) Wirtschaftsrecht (LL. B.) at the Universität Osnabrück. Although the numbers in the first ZEVA column do not, at first glance, appear consistent with the numbers in the second ZEVA column, these numbers are accurate. Six institutions offer five degrees because one degree is offered jointly by the Universities of Bremen and Osnabruck. Bremen is a DJFT Member, but Osnabruck is not. See supra; DJFT Members, supra note 94.

107 See supra notes 94 and 106 (listing the DJFT Members offering ZEVA-accredited degrees and explaining which DJFT institutions have been included).

108 ZEVA has accredited six masters of law programs, four of which are offered by traditional public university DJFT members. See ZEVA, Akkreditierte Masterstudiengänge, http://www.zeva.unihannover.de/akkred/studieng/master.htm (last visited June 25, 2006) (listing these accredited master's degrees offered by DJFT members: 1) Master of Laws (LL. M.) Weiterbildungsstudiengang Law and Finance at the Johann Wolfgang Goethe-Universität, Frankfurt am Main; 2)Master of Laws (LL. M.) Laws and Economics at the Universität Hamburg; 3) Master of Laws (LL. M.) Rechtsinformatik at the Universität Hannover; 4) Master of Laws (LL. M.) Comparative and European Law at the Universität Oldenburg / Universität Bremen (Bremen is a DJFT member but Oldenburg is not)).

${ }^{109}$ Although the numbers in the last three columns of the ZEVA row may appear inconsistent, they are not. Seven institutions offer six accredited master's degrees because one degree is offered jointly by the Universities of Bremen and Osnabruck. Bremen is a DJFT Member, but Osnabruck is not. See DJFT Members, supra note 94.

110 See supra note 94 .

111 Seven percent is the result one achieves if one divides the 3 DJFT degree-granting institutions by 41, which is the total number of traditional university DJFT members. I did not include the private Bucerius Law School or the distance-education program at the FernUniversität in Hagen in the denominator because I did not count the accredited bachelor of law programs offered by these institutions. 
DJFT members, whereas the majority of the accredited bachelor of law degrees were offered by Fachhochschule (University of Applied Science) or universities that do not currently offer a law program leading to the Staatsexamen. ${ }^{112}$

On the other hand, this table shows that approximately forty-three percent of the accredited master's of law degrees were offered by traditional public university institutions that belong to the DJFT.113 Of the nine accredited masters of law degrees offered by the traditional public university members of the DJFT, four different masters degrees were offered by one institution - the University of Münster. ${ }^{114}$ The other five DJFT institutions offering accredited master's of law degrees were the Universities of Bremen, Düsseldorf, Frankfurt am Main, Hamburg, and Hannover. 115 This means that approximately fifteen percent of traditional public university DJFT institutions offered accredited master's of law degrees. ${ }^{116}$ Because this type of data seems useful to law departments contemplating the introduction of new degrees, including accredited degrees, I recommend that a law-related entity collect and publicize this type of data. This data could help institutions decide whether to offer a bachelor or master's degree, whether such a degree should be accredited, and, if so, which agency to use to accredit that degree.

My fourth recommendation regarding quality assurance is that the German legal education community should engage in a vigorous dialogue about whether it would find it desirable to have accreditation handled on a national level by a single, law-specific accreditation organization. As of June 2006, five of the six approved agencies had accredited German law degrees and none of these organizations was a law-specific accreditation agency. ${ }^{117}$ While this might be a desirable situation, it

\footnotetext{
112 See supra note 100.

113 One of the programs is split by a traditional university DJFT member (the University of Bremen) and a non-DJFT member (the University of Oldenburg). In calculating the percentages, I divided the nine DJFT institutions by the 21 degree-granting programs (since there 21 not 22 degree programs).

114 See supra note 104.

115 See Table 2, supra note 102.

116 Fifteen percent is the result of dividing the 6 DJFT degree granting institutions by 41 , which is the total number of traditional university DJFT members. The private Bucerius Law School, distanceeducation program at the FernUniversität in Hagen, and accredited master of law degree programs offered by these institutions are not included.
}

117 A list of existing accreditation and evaluation agencies is available on EvaNet. See Evanet, Nationale Akkreditierung, Evaluation und Qualitätsentwicklung, available at http://evanet.his.de/evanet/links/linkpool_AEQD.php\#AAEe (last visited June 14, 2006). (at the University of Cologne, accreditation is phase 3 of the Bologna Process implementation and is scheduled 
may be useful to discuss the advantages and disadvantages of having a single agency accredit law departments. ${ }^{118}$ As an alternative, the German legal education community could consider whether it would be appropriate and desirable to participate in law-specific accreditation initiatives organized on a European or international basis. For example, the German legal education community might encourage either the European Law Faculties Association (ELFA) ${ }^{119}$ or the newlyformed International Association of Law Schools (IALS) ${ }^{120}$ to serve as an

to begin during Winter Semester 2006-07, after preparation that occurred during academic year 2005-06). See stupra note 90 .

118 In the U.S., for example, the primary law school accreditation agency is the American Bar Association. See ABA Section of Legal Education and Admissions to the Bar, Standards for Approval of Law Schools 2005-06, http://www.abanet.org/legaled/standards/standards.html. See also Association of American Law Schools (AALS), Bylaws and Executive Comnittee Regulations Pertaining To The Requirements of Membership (August 2005), available at http://www.aals.org/about_handbook_requirements.php (The AALS, is a professional organization with membership requirements, acting in an equivalent manner to an accreditation agency); AALS, What is the AALS, azailable at http://www.aals.org/about.php. Compare UK Centre for Legal Education, Assessment in Legal Education, available at http://www.ukcle.ac.uk/resources/assessment/index.html (the UK Centre, founded in 2000, does not conduct assessments but collects information about assessment models, case studies, and literature).

119 European Law Faculties Association, available at http://www.elfaafde.org/html/about_members.html (last visited Nov. 17, 2005) (listing 19 German members, as of August 9, 2005). Although ELFA is not an accrediting agency nor does it have stringent membership requirements as does the AALS, supra, ELFA is engaged in some quality assurance efforts. See, e.g., Quality Assurance, Accreditation and European Legal Education, available at http://elixir.bham.ac.uk/quaacas/index.htm (last visited Nov. 17, 2005) (describing ELFA QUAACAS Committee). ELFA is generally supportive of the Bologna Process, which includes a quality assurance objective, although ELFA has indicated its areas of concern. See European Law Faculties Association, For a European Space of Legal Education: ELFA statement concerning the Bologna-Declaration of the European Ministers of Education of 1999 (adopted May 31, 2002), available at http://www.elfaafde.org/PDF/Sorbonne\%20Bologna/position\%20paper\%20May\%202002\%20English.pdf (last visited Nov. 23, 2005) ("ELFA is very much in favour of the spirit underlying the Bologna Declaration, namely a general concern about the quality, transparency and mobility in European (legal) education, an increase in competitiveness of European institutions of higher education in a globalising world, the achievement of greater compatibility and comparability of systems of higher education, a reduction of student dropup rates in law faculties, and an orientation of university degrees also towards needs of the changing labour market, whilst always maintaining high standards in academic education.")

120 The IALS was formed in October 2005. See International Association of Law Schools available at http://www.ialsnet.org (explains its history and mission as follows:

"The idea for an international association of law schools emerged from several meetings of legal educators from around the world who recognized the growing inter-relationship of norms from transnational legal systems. The first such meeting, held in Florence, Italy, in 2000 consisted of 50 invited legal educators from twenty-seven countries. This meeting led to additional meetings of international legal educators, the most recent of which was held May 2004 in Hawaii. At this meeting, 130 legal educators from forty-seven different countries unanimously adopted a resolution to form a new international association of law schools. In May 2005 a select group of legal educators from fourteen 
accreditation or evaluation agency for German law departments. Because the DJFT recently decided to join the IALS as an observer, it is now in a better position to evaluate whether such international accreditation is realistic or desirable. ${ }^{121}$ Although the German legal education community ultimately might decide that the status quo is preferable and that accreditation should be left to approved German agencies, currently AQAS, ASIIN, AHPGS, ACQUIN, FIBAA, or ZEVA, 122 the time is ripe for a discussion of the advantages and disadvantages of different kinds of accrediting agencies.

It is critical for German law faculties to consider these issues because of the importance of quality assurance issues. If one agrees that "what gets measured matters", 123 then it is hard to think of anything measurable that is more critical to German legal education than quality assurance. To illustrate the importance of a quality assurance system, imagine how differently a German law department might be rated depending on whether a quality assurance agency measures the number of doctoral students per professor; the number of hours per week that professors make themselves available to students; the number of publications (or perhaps pages or perhaps footnotes) collectively published by the law department's professors each year; the number and variety of courses offered to students; the student-faculty ratio; teaching evaluations of faculty by students that award numerical scores; the number of moot court opportunities available to students; whether the faculty attended the highest prestige institutions; the diversity of faculty, which could be measured by the number of different institutions faculty attended, gender, geographic, or viewpoint diversity; or the similarity of the institution to other law departments.

Although it is theoretically possible that a particular law department could score well regardless of which of the above measuring sticks is used, it is more likely that a particular law department would score better on certain criteria than on other criteria. Moreover, some of these criteria seem to point in opposite directions. For

different countries, representing all types of the world's legal systems, gathered in Istanbul, Turkey, and agreed to the terms of a charter for the International Association of Law Schools. In October 2005, the IALS was incorporated under the laws of the District of Columbia in the United States of America."). Id.

121 Deutschen Juristen-Fakultätentages, Beschlüsse des 86. Deutschen Juristen-Fakultätentages (26 May 2006), available at http://www.jura.uni-muenchen.de/einrichtungen/fakultaetentag/beschluesse.pdf (last visited July 12, 2006) (International Association of Law Schools (DJFT 2006/VI) Der Deutsche Juristen-Fakultätentag tritt der International Association of Law Schools als Beobachter bei.).

122 See Akkreditierungsrat, Akkreditierungsagenturen, supra note 89, (listing agencies that have been accredited by the Akkreditierungsrat.)

123 See supra note 73 , and accompanying text. 
example, it is quite possible that the more doctoral students a professor supervises, the less time he or she will have available for each student. In reality, a quality assurance agency is likely to rely on many different factors when evaluating a law department rather than relying on a single factor. But this list should help illustrate the point that a department may be rated quite differently depending on what is measured. Thus, as previously noted, the measuring sticks that are used are likely to influence a law department because, consciously or unconsciously, that department may want to look as good as possible when measured.

If it is true that quality assurance and accreditation standards will affect the shape and nature of German legal education, then it is exceedingly important for the German legal profession to participate in the selection of a quality assurance agency and the development of quality assurance standards by that agency. The German legal education community has a large stake in monitoring quality assurance developments in order to insure that the measuring sticks are consistent with the vision and mission of German legal education, that the measuring sticks are understandable, and that they are meaningful to stakeholders.

One additional reason why German law departments might want to discuss these quality assurance issues is the fact that German students have expressed concerns about the implementation of this particular Bologna Process objective. In a report entitled "Failing Bologna," a leading student organization called freier zusammenschluss von studentInnenschaften, which is known by the acronym "fzs," complained that the overvaluation of peer review leads to "complete intransparency and arbitrariness of the accreditation process." 124 This group set forth its "fear that this intransparency might also lead to an increase in the conformity of programmes and to an overemphasis on being 'fashionable."'125 It also expressed its view that the only national quality assurance mechanism was accreditation, that there was inadequate student representation in many accreditation agencies, and that the premise of the German accreditation system was erroneous. On the latter point, this report stated:

The German accreditation system is founded on the belief that competition between accreditation agencies will increase quality. This is obviously erroneous as demonstrated by the reality of the system. The

\footnotetext{
124 The National Union of Students in Germany, Failing Bologna, State of Implementation of the Bologna Objectives in Germany: Students' National Report for the Berlin Summit on Higher Education, 18 (2003), available at http://www.esib.org/BPC/Countries/Germany/natrep_final.pdf (hereinafter fzs, Failing Bologna).

$125 \mathrm{ld}$.
} 
Accreditation Council is quite weak in comparison to the agencies and cannot regulate competition. ${ }^{126}$

This student report was prepared in 2003; in the 2005 Bologna Process Stocktaking Report, Germany was listed as having made "excellent progress" with respect to the Bologna Process quality assurance objective. ${ }^{127}$ It is certainly possible that in the two years after the fzs report, the problems fzs noted had disappeared. It is more likely, however, that the 2005 Stocktaking Report evaluated items differently than the students. Thus, in light of these student complaints, German law departments might find it useful to consider (or reconsider) how they would like the quality assurance objective implemented for their department and whether they agree with any of the concerns expressed in the fzs "Failing Bologna" report.

My recommendation about the importance of participating in the development of quality assurance and accreditation standards is based in part on my experience in the U.S. During the past twenty years, the criteria used by the official accreditation and membership agencies have changed. Some of the quality assurance factors and benchmarks that have changed include diversity of the faculty; the extent of practical opportunities offered to students; the treatment of clinical faculty; the change from a quantitative to a qualitative requirement regarding libraries; and whether faculty salaries should be included as part of an accreditation system. ${ }^{128} \mathrm{I}$ have observed that when these quality assurance benchmarks have changed, the behavior of U.S. law schools has changed.

An additional reason why quality assurance benchmarks are important is that they provide a source of information that can be used in other, non-official contexts. In the U.S., for example, some of the data collected for law school accreditation purposes also is used by private, for-profit companies that provide rankings of U.S. law schools. ${ }^{129}$ These rankings are unofficial but extremely influential with

126 ld.

127 See supra note 36 , and accompanying text.

${ }_{128}$ See American Bar Association Section of Legal Education and Admissions to the Bar, 2005-06 ABA Questionnaires, available

http://www.abanet.org/legaled/questionnaire/questionnairedocuments.html (last visited Jan. 14, 2006) (the current version of the questionnaire that U.S. law schools must complete before their sabbatical (7 year) ABA accreditation visit); For information about the current AALS membership requirements and site evaluation, see http://www.aals.org/about_handbook.php (last visited April 4, 2006).

${ }^{129}$ U.S. law school rankings appear annually in print in the magazine U.S. News and World Report. Online versions are also available. See http://www.usnews.com/usnews/edu/grad/rankings/law/lawindex_brief.php (last visited June 8, 2006). U.S. law schools are very concerned with the rankings that appear in U.S. News and World 
prospective students. Although law school rankings in Germany have not yet assumed the importance that they have in the U.S., such rankings exist and there is increased interest in rankings. ${ }^{130}$ For example, the CHE already conducts rankings that include law departments ${ }^{131}$ and the Wissenschaftsrat has issued a report that endorses increased use of comparative rankings. ${ }^{132}$ The Wissenschaftsrat plans to pursue the issue of rankings further and has begun a pilot study on this topic. ${ }^{133}$ Thus, it seems quite likely that German law departments will be subject to increased ranking systems in the future and that accreditation data could play a role in these ranking systems.

There are other ways in which the data collected by the official quality assurance agencies might influence German law departments. One could imagine that in the future, in awarding the millions of dollars associated with its Excellence Initiative,

Report. See, e.g., Paul L. Caron, Symposium: The Next Generation of Law School Rankings, 81 INDIANA LAW JOURNAL (INDLJ) 1 (2006). The majority of the deans of ABA-accredited U.S. law schools have written a joint letter to prospective applicants, warning them of the flaws in ranking systems (such as that used by U.S. News and World Report). This letter has been posted on the website of the Law School Admission Council. See LSAC, Law School Deans Speak Out About Rankings (April 2005), available at http:/ / www.lsac.org/pdfs/2005-2006/RANKING2005-newer.pdf (last visited Jan. 16, 2006).

130 See, e.g., Der Deutsche Akademische Austauschdienst (DAAD), Research Rankings in Germany, available at http://www.daad.de/deutschland/forschung/forschungs-rankings/04675.en.html (last visited June 19, 2006) ("Recent years have seen competition in Europe, and especially in Germany, take on new forms and a new quality; in particular, in connection with the establishment of the European Research Area... This is why recent times have seen ranking lists experience a boom in Germany. Ever more and new attempts to rank excellence are coming onto the market all the time.")

131 German university rankings are conducted annually by Der Zeit and the Centrum für Hochschulentwicklung (CHE). See Centrum für Hochschulentwicklung, CHE-Ranking, available at http://www.che.de/cms/?getObject=2\&get Name=CHE-Ranking\&getLang=de (last visited June 8, 2006). If there is an increase in the ability of universities to selectively admit students, these rankings may assume increased importance in the future. See supra note 48; Terry, The Bologna Process: A German Case Study, supra note 2, at \$I(B)(3).

132 Wissenschaftsrat, Recommendations for Rankings in the System of Higher Education and Research Part 1: Research, Drs. 6285-04, (Nov. 12, 2004), available at http://www.wissenschaftsrat.de/texte/628504.pdf (last visited June 13, 2006). This report includes a survey of historic and existing ranking systems in Germany, reviews the ranking systems in other countries, including the U.S., U.K. and Netherlands (including the U.S. News and World Report rankings), recommends that Germany begin a pilot study and recommends that Germany perform international benchmarking with the U.K. and Netherlands. Id. at p. 57. In addition to the $\mathrm{CHE}$ and Wissenschaftsrat rankings, other leading rankings include those of the Die Deutsche Forschungsgemeinschaft (DFG) and the Humboldt Foundation. See DAAD, Research Rankings in Germany, supra note 130.

133 Wissenschaftsrat, Arbeitsprogramm, Pilotstudie Forschungsrating, available at http:/ / www.wissenschaftsrat.de/Arbeitsprogramm/arbeitsprogramm.html (last visited June 13, 2006) (Wissenschaftsrat begin its pilot study on research rankings with the fields of Chemistry and Sociology in July 2005, a report is expected sometime in 2007). $1 d$. 
the German government might ask law departments to submit the kinds of data that a quality assurance agency collected.134 Thus, because the accreditation data could be used for multiple purposes, such as accreditation, rankings, and resource allocation, German law departments should pay close attention to the development and implementation of the Bologna Process quality assurance objective.

\section{The 2005 Recognition of Degrees Objective}

In addition to taking action with respect to the quality assurance Bologna Process objective, I also recommend that the German legal education community take a more active role with respect to implementing the Bologna Process degree recognition objective. As noted earlier, the benchmarks used in 2005 to measure progress on this objective included:

1) implementation of the Diploma Supplement, which is a standardized form that will be attached to a diploma to explain its meaning in terms that all Bologna Process participants will understand;

2) implementation of the European Credit Transfer and Accumulation System (ECTS), which uses a standardized credit system for courses; and

3) ratification of the Lisbon Convention on recognition, which explains how students and degree-holders from another education system will be treated. 135

Although most, if not all, Germany universities use some form of the Diploma Supplement and an ECTS system, ${ }^{136}$ German students have complained about Germany's implementation of both of these items. ${ }^{137}$ With respect to the Diploma Supplement, the fzs report referred to earlier concluded that "[s]trictly speaking,

134 See German Ministry of Education and Research, Initiative for Excellence Competition, available at http://www.bmbf.de/en/1321.php (last visited June 8, 2006).

1352005 Stocktaking Report, supra note 25, at 20-21 (listing benchmarks for the recognition objective).

${ }^{136}$ Id. at 47-48 (Germany's stocktaking results). For additional information, see, e.g., HRK, ECTS / Modularisienung, available at http://www.hrk-bologna.de/bologna/de/home/2000.php (last visited June 8, 2006) (contains extensive, non-law specific information on ECTS); HRK, Diploma Supplement, arailable at http:/ / www.hrk-bologna.de/bologna/de/home/1997.php (last visited June 8, 2006).

137 fzs, Failing Bologna, supra note 124, at 9 (“The National Union of Students in Germany (fzs) is deeply concerned about the incoherent implementation of the Bologna Process in Germany. The objectives and measures of the Bologna Process are not given equal importance. Instead, there is political focus on isolated measures that in most cases are not properly implemented." ) 
there is no common Diploma Supplement in Germany as the different variations differ quite significantly." 138 This student report was equally harsh with respect to Germany's implementation of the ECTS system, with the students concluding that the ECTS system had been a failure:

The introduction of ECTS in Germany has failed. Quite a number of [higher education institutions] have introduced credit point systems that claim to be compatible with ECTS. Most cannot live up to that claim. There are two main reasons for this: Credits are not workload based and the systems used are incompatible with each other. The resistance to change is typified by the reluctance to allocate the number of credit points based on the actual workload instead of taking the contact hours as a basis. As a result almost all institutions are in breach of the decision of KMK (KMK 2000-09-15), which states that 1 credit point should be equivalent to 30 hours of work. 139

Although this fzs report is dated 2003, two years before Germany received its "very good progress" rating in the 2005 Stocktaking Report, one wonders whether these problems might still exist. It is quite easy to imagine that these problems have not yet been corrected and that the 2005 Stocktaking Report failed to consider these particular problems. In light of student complaints about German implementation of ECTS and the Diploma Supplement and given the continued attention these issues will receive as a result of the Bologna Process, German law departments may be asked to pay more attention to their ECTS system and to the particular Diploma Supplement they use.

Unfortunately, however, there is little comparative data available to German law departments to help them consider their implementation of these issues. ${ }^{140}$ I

\footnotetext{
138 Id. at 11 .

139) Id. at 13

140 Compare Deutscher Juristen-Fakultätentag, Prüfung von Schlüsselqualifikationen, available at http://www.jura.uni-muenchen.de/einrichtungen/fakultaetentag/aktuell/sq.pdf (last visited Nov. 25, 2005); Deutscher Juristen-Fakultätentag, Angebote der Universitäten zur Examensvorbereitung, available at http://www.jura.uni-muenchen.de/einrichtungen/fakultaetentag/85/angebotexamen.pdf (last visited Nov. 25, 2005). See Terry, The Bologna Process: A German Case Study, supra note 2, at §III(A)(3) (noting that the HRK Bologna Information Center website has collected a tremendous amount of information, including some that is department-specific, but that none of the data addresses the use of ECTS or the Diploma Supplement by German law departments nor is such data available on the webpages of the Deutscher Juristen-Fakultätentag (DJFT), the European Law Faculties Association or the European Law Students Association (ELSA). The Deutscher Juristen-Fakultätentag (DJFT) webpage, for
} 
therefore recommend that some organization collect data regarding the use of ECTS by law departments. Such data could show the ECTS awarded for specific courses and the ECTS required in order to complete various kinds of degrees, such as a bachelor of law, master of law, or Diplom-Jurist degree. Some data of this type already is available on the DJFT's bachelor and master's degree chart, ${ }^{141}$ but it would be useful if this kind of data were available for all bachelor of law and master's of law degrees.

This type of comparative ECTS data could make law departments' tasks easier because it would provide a pool of information useful for a variety of purposes. For example, if a law department is considering offering a new master's of law degree or a bachelor of law degree, this data could help envision different ways to structure the degree. In other words, it would help departments avoid "reinventing the wheel."

One goal of the Bologna Process is to promote mobility among students. ${ }^{142}$ Thus, law faculties are likely to be under increasing pressure in the future to accept students from other institutions into their master's degree or doctorate programs. ${ }^{143}$ Comparative ECTS data also could be useful if a university law department is asked to admit to their master's of law degrees either a student from another country or a student from another German institution. Moreover, this comparative ECTS data could be useful to German legal educators and regulators regardless of their views on recognition because it would help them develop their positions and present their views. ${ }^{144}$

example, includes information relating to the 2003 legal education reforms, including the new curricular requirements, does not include any information about the ECTS credits offered for various courses or information about the implementation of the Diploma Supplement.)

141 See supra note 92.

142 See Action Line \#4, supra note 21.

${ }_{143}$ Id. This pressure is likely to come not just from the Bologna Process, but from the European Court of Justice. Christine Case C-313/01, Morgenbesser v. Consiglio dell'Ordine degli avvocati di Genova, 2003 ECR I-13467, 1 C.M.L.R. 24, Celex No. 601J0313. This case held that a bar had to have a recognition procedure to evaluate whether to admit to its training-apprenticeship program a woman who had completed law studies in another country, but was not yet a licensed lawyer. Similar principles might require university law departments to have procedures in place to decide whether to accept into their degree programs students who began their studies elsewhere.

144 Not all commentators have been supportive of the idea of using recognition principles in the field of law. See, e.g., JUMIKO November 2005 Resolution, supra note 61, at $q 2$ („Das erfordert nach wie vor juristische Ausbildungssysteme nationalen Zuschnitts. Diese notwendige Ausrichtung der Ausbildungssysteme auf die nationalen Rechtsordnungen lässt eine generelle Gleichbehandlung von nationalen und internationalen rechtswissenschaftlichen Abschlüssen und Studienleistungen nicht zu."). On the other hand, German legal educators and regulators have a limited ability to resist recognition 
As a corollary, I also recommend that some entity collect and publish data about the number of foreign students who seek recognition under the Lisbon Convention. German law departments should find it useful in the future to have comparative data available that tells them the extent to which other law departments are facing this issue and how other law departments - both within and outside of Germany are responding to the issues raised by ratification of the Lisbon Convention. Among other things, this data could help departments see what, if any, prerequisites might be required to begin a master's degree.

My third recommendation is that after this data is collected, German law departments should conduct a vigorous discussion about the application of the ECTS system to various kinds of law degrees. Although Bologna Process members have agreed that the ECTS is the touchstone that will be used for measurement and comparison purposes, there are still many unanswered questions, including the question of whether a German bachelor of law degree should be three or four years long. ${ }^{145}$ In my view, it is much more efficient and fair to students to have a standardized answer to this question. I therefore recommend that German legal educators discuss this issue collectively and do so in terms of ECTS. Otherwise, students who are not sophisticated are likely to be caught in a trap in which they are surprised and disappointed by the fact that they cannot move to another country or another degree program because their original program was too short.

My final set of recommendations for the degree recommendation objective is that some entity should collect the existing law-related Diploma Supplements. That way, if a German law department offers a new degree or program, it will have a model it can follow for its Diploma Supplement. Such data sharing should also lead to more uniform Diploma Supplements, which should further the goal of

given the European Court of Justice Morgenbesser case, supra note 143 and the European Union directives that already incorporate recognition principles and permit lawyers from one EU country to practice in another EU country. For additional information on these directives, See Terry Interview with "Crossing the Bar.Com" about NAFTA, GATS, and the EU Regulation of Lawyers (May and Dec. 2001), available

http://www.personal.psu.edu/faculty/1/s/lst3/Electronic\%20Interview\%20of\%20Professor\%20Laurel \%20Terry.doc (last visited June 8, 2006).

115 See, e.g., Dauner-Lieb, supra note 67, at 5 (arguing in favor of a four-year bachelor of law degree); HRK, Statistiken zur Hochschulpolitik, Sommersemester 2006, No. 1/2006 (May 2006) at para. 15-16, available at http://www.hrk.de/de/download/dateien/HRK_Doku1_2006_SoSe2006.pdf (noting that some institutions offer a three year bachelor degree whereas other institutions offer a four year bachelor degree and that it is difficult to compare and evaluate the new bachelor degree since the length of study time is different and since some bachelor degrees are offered by universities and some are offered by the Fachhochschule) (hereinafter 2006 German Report on the Introduction of Bachelor and Master Degrees). 
having a standardized, easily-readable supplement. 146 Such action might help minimize complaints from German students about Germany's implementation of the Diploma Supplement Bologna Process benchmark. ${ }^{147}$

\section{The 2007 Bologna Process Priority Objectives and Other Bologna Process Action Lines}

As explained in the prior section, the Bologna Process countries have agreed to prepare a new Stocktaking Report in time for their 2007 London meeting. ${ }^{148}$ It is likely that this Stocktaking Report will again develop benchmarks and use a colorcoded approach that places pressure on countries to conform to those benchmarks. I recommend that the German legal education community participate in the development of these benchmarks. ${ }^{149}$ It is too late for German legal educators to help develop the benchmarks that were established in 2005 and that will continue to be used. But is it not too late for the German legal community to monitor the development of the 2007 benchmarks and to offer comments to the extent that any benchmarks seem inappropriate. Despite the potential importance of these benchmarks, as of mid-2006, German legal educators or regulators did not appear to be sponsoring any discussions of these issues or collecting data regarding them. ${ }^{150}$ In my view, this puts the German legal education community at a disadvantage because it means they will be measured by standards they have not helped develop. Those who design these standards may - or may not - be familiar with the needs and goals of German legal education.

I also recommend that the German legal education community monitor and participate in the activities related to the other Bologna Process "Action Lines."

146 See, e.g., Diploma Supplement Funktion - Inhalte - Umsetzung, Service-Stelle Bologna, Beiträge zur Hochschulpolitik, p. 326 (2005), aoailable at http://www.hrkbologna.de/bologna/de/download/dateien/DS-pub_internetversion.pdf (last visited Nov. 15, 2005). This document includes the reports and presentations from four conferences on the Diploma Supplement that the HRK sponsored during Spring 2005, together with a summary of the discussions and additional relevant working materials. Id. at 2. The German-language version of the Diploma Supplement is found on pages 284-286.

147 See supra note 138, (citing fzs report complaining about the implementation of the Diploma Supplement benchmark).

${ }^{148}$ See supra note 38 , and accompanying text.

${ }^{149}$ See Stocktaking Report, supra note 25 , at 40-41, 78-79.

150 See generally Terry, The Bologna Process: A German Case Study, supra note 2, at §III (describing the information available on the websites of the HRK, DJFT, BRAK, DAV, ELFA and ELSA, none of which is specifically focused on law-specific issues related to the development of the 2007 Bologna Process Stocktaking Report or the other Bologna Process Action Lines). 
There are a number of conferences that have been held on Bologna Process topics that are not included in the 2005 or 2007 priority items. ${ }^{151}$ Because potential approaches and policies are being discussed at these conferences, it would be appropriate for the DJFT or another organization to appoint one or more committees that would be responsible for monitoring developments related to each of the Bologna Process' ten action lines.

\section{E. Conclusion}

The Bologna Process is an exceedingly ambitious undertaking that proposes to remake the face of higher education in Europe and that already has led to significant changes in German education. Judging by the hundreds of thousands of pages that are now on German internet websites, both the German government and German education leaders are fully committed to implementing the Bologna Process. Moreover, legal education institutions elsewhere in Europe already have made significant changes as a result of the Bologna Process. Thus, in my view, it is unlikely that German legal education will be able to resist for long pressure to implement the Bologna Process initiatives.

To date, the German legal education community has concentrated its discussion and interest in the Bologna Process almost exclusively on one issue - the bachelormaster degree issue. ${ }^{152}$ Although this clearly is a very critical issue, it is not the only important issue raised by the Bologna Process. I therefore recommend that the German legal education community take a number of specific steps with respect to the Bologna Process, including the following actions:

Recommendations Regarding the Quality Assurance Objective:

\footnotetext{
151 For numerous conferences and papers listed on the HRK, Service-Stelle Bologna webpage, see, e.g., supra note 75. HRK, Tagungsdokumentation 2004 - 2006, available at http://www.hrkbologna.de/bologna/de/home/1945.php (last visited June 20, 2006) (the May 2006 Vierte Tagung included information on mobility (action line 4) and other topics).

152 The German legal profession faces two different sets of issues with respect to the two-degree cycle bachelor-master issue. The first issue is whether German institutions should offer a bachelor of law or master's of law degree in addition to or in lieu of the Staatsexamen/Diplom-Jurist degree. The second issue is the effect of a bachelor and master degree system on the lawyer qualification issue, including the type of degree that is required to enable one to qualify as a lawyer. Although there obviously is some overlap between these issues, they are separate issues. I recommend that when debating the Bologna Process two-degree cycle issue, German commentators clearly indicate whether they are addressing the lawyer qualification system or the merits of adding new degrees to the educational system.
} 
Some entity should collect and publish data regarding the existing quality assurance initiatives in German law departments;

The German legal community should engage in a vigorous dialogue about the factors that a quality assurance system should measure and whether these factors should differ depending on the nature of the law program;

Some entity should collect and publish information about all of the existing legal studies program, including bachelor of law and master's of law degrees. It would also be useful to have data easily available that discloses the number and type of accredited law degrees approved by each of the accrediting agencies authorized by the Akkrediterungsrat and the type of higher education institution offering the accredited law degree; and

The German legal community should engage in a vigorous dialogue about whether it would find it desirable to have quality assurance and accreditation initiatives handled on a national level by a single accreditation agency, whether it would be desirable to have accreditation handled by a law-specific organization, and whether it would want to participate in European or international accreditation initiatives.

Recommendations Regarding the Recognition of Degrees Objective:

Some entity should collect and publish ECTS data for all types of German legal education programs, not just accredited law degree programs;

Some entity should collect and publish data about the number of foreign students who seek admission to German law degree programs and seek recognition under the Lisbon Convention; 
German law departments should conduct a vigorous discussion about the application of the ECTS system to various kinds of law degrees; and

Some entity should collect and publish the existing law-related Diploma Supplements.

Recommendations Regarding the 2007 Bologna Process Priority Objectives and Other Bologna Process Action Lines

The German legal education community should participate in the development of benchmarks that will be used in the 2007 Stocktaking Report; and

The German legal education community should monitor and participate in the activities related to the other Bologna Process Action Lines, perhaps by having the DJFT appoint one or more committees that would be responsible for monitoring developments related to each of the Bologna Process' ten action lines.

In sum, the Bologna Process is an important development that could significantly influence German legal education. It is important for the German legal community to be familiar with all of the Bologna Process issues. It is equally important for the German legal community to share its views with the important leaders and stakeholders that are helping to shape the Bologna Process. The German legal education community should work to ensure that implementation of the Bologna Process is understandable, consistent with the vision and mission of German legal education, and meaningful to its stakeholders. 